\title{
A kémiai elemek légköri ülepedése és agronómiai/környezeti jelentôsége
}

\author{
KÁDÁR IMRE - KONCZ JÓZSEF - RAGÁLYI PÉTER \\ MTA Talajtani és Agrokémiai Kutatóintézet, Budapest
}

\section{Összefoglalás}

2005-2008 között három éven át havi gyakorisággal vizsgáltuk két kísérleti telepünkön a csapadékvizek összetételét és elemhozamát. Az analízis 26 tulajdonságra terjedt ki: $\mathrm{pH}, \mathrm{EC}, \mathrm{NO}_{3}-\mathrm{N}, \mathrm{NH}_{4} \mathrm{~N}$, valamint a fontosabb makro-és mikroelemek meghatározására. Méréseink a teljes, tehát a nedves és száraz ülepedés együttes hatását tükrözik. A szúrletből közvetlenül mértük a Ca, Mg, K, Na, S, B elemeket, valamint a karbonátot, kloridot, ammóniát, nitrátot. A szúrletet az eredeti térfogat 1/4-ére bepároltuk $\mathrm{HNO}_{3}$ hozzáadása után a mikroelemek elemzése céljából. A mérések a karbonát, klorid, ammónia, nitrát kivételével ICP-OES készülékkel történtek. Fớbb megállapítások:

- Általában a minimális havi csapadékösszeghez volt köthetố a maximális vezetốképesség (EC), $\mathrm{pH}, \mathrm{NH}_{4} \mathrm{~N}, \mathrm{Ca}, \mathrm{Na}, \mathrm{K}$ koncentrációja. A legnagyobb elemhozamokat ugyanakkor a csapadékos hónapok biztosították. Az 5 pH alatti savanyú csapadék salétromsavat képezó $\mathrm{NO}_{3}$-N-ben gazdag, $\mathrm{NH}_{4}$-N-ben szegény volt az Örbottyán állomásunkon. A közeli cementgyár emissziója miatt 2006. február és március havi csapadékban nagyságrenddel dúsult a $\mathrm{Ca}, \mathrm{Mg}, \mathrm{Na}, \mathrm{Sr}$, valamint jelentôsen emelkedett az $\mathrm{NH}_{4}-\mathrm{N}, \mathrm{S}, \mathrm{Zn}, \mathrm{As}, \mathrm{Cr}, \mathrm{Pb}$ koncentrációja. A pH 7,0-re emelkedett ezen a termôhelyen.

- A mezőföldi állomáson a téli hónapok elemhozamai kicsik. A melegebb májusjúlius hónapok között az $\mathrm{NH}_{4}$ - $\mathrm{N}$ koncentrációja 10-20-szorosa az $\mathrm{NO}_{3}$ - $\mathrm{N}$ koncentrációnak. A környezô termékeny humuszos talajfelszín, a trágyázás, a közeli állattenyésztô telep jelentőss $\mathrm{NH}_{3}$ emissziót képez. Ekkor nagy a $\mathrm{NH}_{4} \mathrm{~N}, \mathrm{Ca}, \mathrm{Na}, \mathrm{K}$ lúgosító kationok mennyisége a csapadékvízben, a pH januártól júniusig emelkedhet. 
- A légköri csapadékkal okozott talajdepozició kg/ha/év mennyisége az alábbi tág határok között változott telepeinken: $\mathrm{NO}_{3}-\mathrm{N} 5-20 ; \mathrm{NH}_{4}-\mathrm{N} 10-31$; összes $\mathrm{N} 30-48$; Ca 6-60; K 6-16; S 2-21; Na 4-13; Mg 2-16; P 2-6 kg/ha/év. Az általunk mért kiülepedés a $\mathrm{Zn}, \mathrm{Mn}, \mathrm{Fe}, \mathrm{Cu}, \mathrm{B}$ elemek esetében közelálló a korábbi hazai, illetve ausztriai mérések eredményéhez. Az $\mathrm{Pb}, \mathrm{Ni}, \mathrm{Cd}$, Co nehézfémek kiülepedését nagyságrenddel kisebbnek találtuk, mely az 1990 óta egész Európára jellemzó drasztikus nehézfém-emisszió csökkenését tükrözi.

- A légköri csapadék elemhozamának agronómiai és környezeti jelentôsége nem elhanyagolható. Számításaink szerint pl. a mezőföldi csernozjom termóhelyen egy közepes, 5 t/ha kalászos gabona szemterméssel és a hozzátartozó mintegy 5 t/ha mellékterméssel felvett K 10; Mg 15; P 20; Ca és N 30; S 40\%-át fedezheti. Amenynyiben kombájn betakarításnál csak a szemtermés elemtartalmával számolnak, mivel a melléktermés a táblán marad és visszakerül a talajba, a légköri forrás fedezhetné a P 25; K 45; S és a Ca 100-300\%-át. A szembe épült Na mennyiségét pedig nagyságrenddel meghaladhatná.

- A légköri ülepedés többé-kevésbé fedezheti a Mo, Ni, Se mikroelemek szemtermésbe épült mennyiségét, a Zn szükségletét mintegy 60\%-kal meghaladhatja. A B, $\mathrm{Ba}, \mathrm{Cu}$, Sr kiülepedés többszöröse az 5 t/ha szemtermés igényének. Agronómiailag elốnyösnek minôsülhet a $\mathrm{Cu}, \mathrm{Mo}, \mathrm{Se}, \mathrm{Zn}$ elemekkel történố légköri trágyázás, amennyiben a talaj ezen elemekben nem ( $\mathrm{Zn}, \mathrm{Cu})$ vagy nem kellôen (Mo, Se) ellátott. Környezeti szempontból nemkívánatos jelenség viszont a talaj Cd, $\mathrm{Hg}$ és $\mathrm{Pb}$ nehézfémekben való gazdagodása, különösen hosszútávon. Ezek a toxikus fémek a vizekbe, illetve az élelmiszer és takarmány növények felületére jutva közvetlenül is károsíthatják az élelmiszerláncot.

- Méréseink szerint kísérleti telepeinken a 3 év alatt évente az alábbi minimálismaximális kiülepedést regisztráltuk: Zn 112-1391; Sr 30-202; Cu 21-153; Fe 42-119; Ba 40-79; Mn 33-62; B 0-33; Pb 2-4; Ni, Cr, Mo 0-6; As 0-4; Hg 0-1,5; Co 0,4-0,7; Cd 0-0,3 g/ha/év. A pH 4,2-7,0 között, az elektromos vezetôképesség 25-1996 $\mu \mathrm{S} / \mathrm{cm}$ tartományban ingadozott.

Kulcsszavak: légköri ülepedés, makro- és mikroelemek, agronómiai jelentőség, környezeti következmények 


\title{
The aerial deposition and agricultural/environmental importance of chemical elements
}

\author{
I. KÁDÁR- J. KONCZ - P. RAGÁLYI \\ Research Institute for Soil Science and Agricultural Chemistry \\ of the Hungarian Academy of Sciences (RISSAC), Budapest
}

\begin{abstract}
Summary
Composition of precipitation and element load originated by rainwater were examined monthly between 2005 and 2008 on two Experimental Stations of the Research Institute for Soil Science and Agricultural Chemistry of the Hungarian Academy of Sciences. Twenty-five characteristics were analysed: $\mathrm{pH}, \mathrm{EC}, \mathrm{NO}_{3}-\mathrm{N}, \mathrm{NH}_{4}-\mathrm{N}$, and the concentration of the main macro- and microelements. This observation represents the dry and wet depositions together. $\mathrm{Ca}, \mathrm{Mg}, \mathrm{K}, \mathrm{Na}, \mathrm{S}$ and $\mathrm{B}$ elements as well as carbonate, chloride, ammonia and nitrate were directly measured from the filtrate of the precipitation. Then the filtrate was graduated to $25 \%$ of its original volume with the addition of $\mathrm{HNO}_{3}$ for the microelement analysis. Measurements were made by ICP-OES device excluding carbonate, chloride, ammonia and nitrate. The main results:

- Generally, the lower amount of monthly precipitations resulted in higher EC, $\mathrm{pH}$, $\mathrm{NH}_{4}-\mathrm{N}, \mathrm{Ca}, \mathrm{Na}, \mathrm{K}$ concentrations. The highest element yields however, were typical for the wet months. Acidic precipitation under $\mathrm{pH} 5$ was rich in nitric acid forming $\mathrm{NO}_{3}-\mathrm{N}$, but poor in $\mathrm{NH}_{4}-\mathrm{N}$ at the Experimental Station in Ôrbottyán. Emission of the nearby cement plant caused an increase of $\mathrm{Ca}, \mathrm{Mg}, \mathrm{Na}$, Sr elements with an order of magnitude compared to the other months and the concentrations of $\mathrm{NH}_{4}-\mathrm{N}, \mathrm{S}, \mathrm{Zn}$, As, Cr, Pb also lifted considerably in the precipitation in February and March 2006 (see: Table $5,1^{\text {st }}$ half of the year). The $\mathrm{pH}$ reached 7.0 at this site.

- Depositions were small at the Mezőföld Station in winter. During the warmer months May, June and July $\mathrm{NH}_{4}-\mathrm{N}$ concentration exceeds the $\mathrm{NO}_{3}-\mathrm{N}$ concentration 10-20 times. The neighbouring fertile and humus rich soils, the fertilization, as well as the nearby animal husbandry farm make considerable $\mathrm{NH}_{3}$ emission. In this period, the concentration of $\mathrm{NH}_{4}-\mathrm{N}$, Ca and $\mathrm{K}$ alkalinising cations could rise the $\mathrm{pH}$ in the precipitation, and the $\mathrm{pH}$ increased from January to June.

- Aerial deposition varied widely at both sites representing the following values in kg/ha/year unit: $\mathrm{NO}_{3}-\mathrm{N} 5-20$; $\mathrm{NH}_{4}-\mathrm{N}$ 10-31; total $\mathrm{N} 30-48$; Ca 6-60; K 6-16; S 2-21; Na 4-13; Mg 2-16; P 2-6. The deposition of $\mathrm{Zn}, \mathrm{Mn}, \mathrm{Fe}, \mathrm{Cu}, \mathrm{B}$ elements in
\end{abstract}


these sites were similar to previous Hungarian and Austrian data, however $\mathrm{Pb}, \mathrm{Ni}$, $\mathrm{Cd}$, Co depositions were lower with an order of magnitude, which demonstrates the result of the successful heavy metal pollution control in Europe since 1990.

- Aerial deposition has considerable agronomical and environmental significance. According to the data obtained within this study the aerial deposition could substitute for $10 \% \mathrm{~K}, 15 \% \mathrm{Mg}, 20 \% \mathrm{P}, 30 \% \mathrm{Ca}$ and N, 40\% S element demand of an average $5 \mathrm{t} /$ ha cereal grain yield with its $5 \mathrm{t} /$ ha straw at the Mezóföld Station on this chernozem soil. When using combine-harvesting, the straw remains at the site and only the grain is removed, so $25 \% \mathrm{P}, 45 \% \mathrm{~K}, 100-300 \% \mathrm{~S}$, Ca and several fold $\mathrm{Na}$, $\mathrm{N}$ element demand could be replaced with the aerial deposition.

- Atmospheric deposition may more or less compensate the amount of Mo, Ni, Se built in grain, while exceed it by about $60 \%$ with $\mathrm{Zn}$. The deposition of $\mathrm{B}, \mathrm{Ba}, \mathrm{Cu}$ and $\mathrm{Sr}$ is several times higher than found in the grain yield. The aerial fertilization with $\mathrm{Cu}, \mathrm{Mo}$, Se and $\mathrm{Zn}$ seems to be advantageous since the site is poor in $\mathrm{Zn}$ and $\mathrm{Cu}$, or not satisfactory supplied with Mo and Se elements. However, the load of $\mathrm{Cd}, \mathrm{Hg}$ and $\mathrm{Pb}$ is environmentally disadvantageous, especially on long-term. The latter harmful heavy metals can also get into waters, onto the surface of crops and directly damage the food chain.

- The following minimal - maximal depositions were measured on the two Experimental Sites: Zn 112-1391; Sr 30-202; Cu 21-153; Fe 42-119; Ba 40-79; Mn 33-62; B 0-33; Pb 2-4; Ni, Cr, Mo 0-6; As 0-4; Hg 0-1.5; Co 0.4-0.7; Cd 0-0.3 g/ha/year. The $\mathrm{pH}$ varied between 4.2 and 7.0 while electrical conductivity between 25 and $1996 \mu \mathrm{S} / \mathrm{cm}$.

Key words: aerial deposition, macro- and microelements, agricultural importance, environmental consequences.

\section{Bevezetés és irodalmi áttekintés}

A növények alapvetôen a talajból és a levegôből táplálkoznak. Az atmoszférából származó $\mathrm{CO}_{2}$, valamint a csapadékból vagy a talajból származó $\mathrm{H}_{2} \mathrm{O}$ biztosítja a fotoszintézishez szükséges összetevők 90-95\%-át. A növények szárazanyagának átlagosan 45-50\%-át a C, 40-42\%-át az $\mathrm{O}_{2}, 5-6 \%$-át a $\mathrm{H}$ alkotja. Igaz, hogy a terméseink nagyságát gyakran éppen a talajból felvett 5-10\%-ot kitevô oldható ásványi elemek mennyisége határozza meg a szárazföldi és a vízi rendszerekben egyaránt (Kádár 1992). 
Az állati vagy emberi légzés, valamint az energiahordozók égetése, a bomlás, rothadás termékei a levegôt „elrontják”, szennyezik. Ismeretes, hogy Priestley 1775-ben igazolta, hogy a növények az ilyen levegôt megtisztítják. Amikor az üvegharang alá egy cserép növényt tett, az egér életben maradt. Később felfedezte és meghatározta az oxigént is. Ingen-Housz 1779-ben rámutatott, hogy a folyamat csak fény jelenlétében megy végbe. Fény hiányában a növények is „elrontják” a levegôt. Saussure (1804) a levegô és különböző gázok hatását vizsgálta a növényre, kísérletesen bemutatva a $\mathrm{CO}_{2}$ asszimilációját és az $\mathrm{O}_{2}$ termelését fényben. A növény elpusztul $\mathrm{CO}_{2}$ hiányában, C-forrásul a légkör szolgál. A hamuelemeket pedig döntően a talajból nyeri vízben oldott sók formájában.

A légkör kereken 78 tf\% $\mathrm{N}_{2}$-ből, 21\% $\mathrm{O}_{2}$-bôl és 1\% egyéb gázokból, döntôen argonból áll. A levegô összetételének kutatása több mint két évszázada tart. Mészáros (2005) átfogó tanulmánya arról szól: „Hogyan fedezték föl a levegôt?”. A N felfedezése Rutherford 1772-ben végzett munkájához köthető. A XIX. század az ózon és a nemesgázok, a XX. század fóképpen a nyomokban előforduló gázok és az aeroszol részecskék kémiájának időszaka. A légkör állandó összetevôin kívül számos egyéb gáznemú, cseppfolyós és szilárd halmazállapotú anyagot tartalmaz kis koncentrációban. Ezek a nyomanyagok, üvegházhatású gázok, szennyezôdések részben természetes forrásból (vulkanikus és kozmikus porok, óceán és talajfelszín kibocsátásai stb.), részben emberi tevékenységből erednek.

Liebig (1840-1876) tévesen feltételezte, hogy a talaj nem tud N-t szolgáltatni, mert csupán az atmoszférából „kölcsönzött” N-t tartalmazza. Szerinte a növényi N-felvétel forrása a légkör ammónia és nitrát készlete. Különösen a nagylevelû́ takarmánynövények N-ellátásában hangsúlyozta a légkör szerepét. A pillangósok N-kötése ekkor még nem volt tisztázott. A szerző 1826. és 1827. években 77 esôvíz analízist végzett. Megállapítja, hogy: „Minden esőzés megszabadítja az atmoszférát az ammóniától és a salétromsavtól.” Az $\mathrm{NH}_{4}-\mathrm{N}$ a hóból nyert vízből sem hiányzik és maximumát az esôzés/havazás kezdetén tartalmazza.

Irodalmi adatokat összegezve hangsúlyozza, hogy az esôvíz általában télen gazdagabb ammóniában, mint nyáron. Melegebb évszakban több nitrát képződik, különösen zivatarok idején. A nitrát és az ammónia tartalma között fordított arány állhat fenn. A több csapadék N-hozama is több. A városok felett több N képződik. Lyonban pl. 1853-ban 38,2 kg N jutott 1 ha területre. A harmat, 
köd és zúzmara $\mathrm{NH}_{4}-\mathrm{N}$ tartalma kiugró lehet. Míg a gleccserjég megolvasztott vízében $2 \mathrm{mg} / \mathrm{l}$, a zúzmara vízében $70 \mathrm{mg} / \mathrm{l}$, Párizsban a súrú köd összegyújtött vízében $138 \mathrm{mg} /$ liter ammóniát találtak. Harmattal, ködös szitálással, zúzmarával annyi $\mathrm{NH}_{4}-\mathrm{N}$ juthat esetenként a talajba, mint az éves esôvel. Különösen igaz lehet ez a csapadékszegény fennsíkokon, ahol a növények víz-és N-szolgáltatásához egyaránt érdemben járulhat hozzá (Liebig 1840-1876).

Németországban az elsố mezőgazdasági kísérleti állomás 1851-ben létesült Lipcse mellett, Möckernben. Nobbe szerint (cit. in: Deller 1988) alig 15 évvel késôbb már 21 kísérleti állomás múködött. Az állomásokon rendszeresen gyújtötték a csapadékot és összetételét is mérték. Itthon Kazay (1904) vizsgálta a csapadék ammónium és nitrát koncentrációját Ó-Gyallán 1902-1904 között. $\mathrm{Az} \mathrm{NH}_{4}-\mathrm{N}$ kereken $12 \mathrm{~kg} / \mathrm{ha}, \mathrm{NO}_{3}-\mathrm{N} 5 \mathrm{~kg} /$ ha volt 1992-ben, tehát $17 \mathrm{~kg} / \mathrm{ha} / \mathrm{év}$ $\mathrm{N}$-ülepedést talált. Irodalmi adatokra utalva konstatálja, hogy az $\mathrm{NH}_{4}-\mathrm{N} 2-3$-szor meghaladhatja a $\mathrm{NO}_{3}-\mathrm{N}$ mennyiségét. $\mathrm{Az} \mathrm{NH}_{4}-\mathrm{N}$ fóként az alacsonyan úszó felhôk csapadékában dúsulhat, mert jórészt a föld felszínérôl kerül a levegőbe. Maximuma januárra, minimuma júliusra esik, mert a víz kevesebb gázt tud elnyelni nagyobb hôfokon. Az elsô esốcseppek, nyáron pedig a jégesố gazdag ammóniában. Agronómiai jelentôségére utalva a csapadékkal bejutó N-nek az alábbiakat jelenti ki: „Egy-egy kövér esô annyi termékenyító nitrát és ammónia vegyületet hoz a földre könnyen asszimilálódó állapotban, hogy érték tekintetében $30 \mathrm{~kg}$ mútrágyával felér."

Kozák és Mészáros (1971) összefoglalták a csapadékvíz összetételére vonatkozó irodalmi adatokat érintve Európa, Észak-Amerika, Afrika, Ausztrália közléseit. Mintavételeket 1968-1970 között 8 meteorológiai állomáson végeztek Magyarországon. Meghatározták az esôvíz pH-ját, elektromos vezetôképességét, valamint a fontosabb makroelemek koncentrációit. Az ülepedést kg/ha/év adatokkal jellemezték. Az évek és a mintavételi helyek átlagában $15 \mathrm{~kg} \mathrm{~N}(9 \mathrm{~kg}$ $\left.\mathrm{NH}_{4} \mathrm{~N}+6 \mathrm{~kg} \mathrm{NO}_{3}-\mathrm{N}\right), 24 \mathrm{~kg} \mathrm{~S}, 28 \mathrm{~kg} \mathrm{Ca}, 9 \mathrm{~kg} \mathrm{Na}$ és Cl, $7 \mathrm{~kg} \mathrm{~K}$ és 0,1-0,2 kg P volt az ülepedés. Véleményük szerint ..."A csapadék elsôsorban mint S-forrás lehet jelentốs a növényi táplálásban."

A mért adatok között kapcsolatokat keresve megállapították, hogy a csapadék mennyiségével a koncentráció csökken, a terhelés viszont nó. Az összetételt a talajfelszín befolyásolja. A karbonátos, szikes talajú Alföldön nő a Ca, $\mathrm{Na}$, $\mathrm{K}, \mathrm{Cl}$ mennyisége, mely kiugró volt pl. a Hortobágy-halastó állomáson. Az elemek dúsulása követi az elektromos vezetôképességet. A koncentrációk télen nagyobbak, mert kevesebb a csapadék, lecsökken a légcsere és a fútés is szeny- 
nyez. A pH pozitív korrelációt mutatott a $\mathrm{Ca}^{2+}, \mathrm{K}^{+}, \mathrm{Na}^{+}, \mathrm{Mg}^{2+}, \mathrm{NH}_{4}^{+}$kationok mennyiségével, maximumát az Alföldön találták. $\mathrm{A} \mathrm{SO}_{4}{ }^{2-}$ és a $\mathrm{NO}_{3}$ - anionok és a pH közötti összefüggés nem volt igazolható, mely elvileg negatív lehetne. Az $\mathrm{NH}_{3}$ forrása fơként a karbonátos talaj, nagyobb állatsúrúség esetén az állati vizelet és a települések, szeméttelepek (Kozák és Mészáros 1971).

Munger (1982) az Egyesült Államokban arra utal, hogy a savas csapadék fó oka a szénégetés által emittált $\mathrm{S}$ és $\mathrm{N}$, illetve a légkörben felhalmozódó $\mathrm{H}_{2} \mathrm{SO}_{4}$ + $\mathrm{HNO}_{3}$ elegye. Az USA középnyugati területének csapadékvíz kémiáját nyugatról a bázikus por, szélerózió és a préri-talajok múvelt felszínérôl felszabaduló ammónia, míg keletről az ottani ipar által kibocsátott savképzô anyagok mérlege alakítja. A pH 4,5-6,5 között változhat. A savas csapadék, a növekvő savterhelés veszélyezteti az élővizeket és az érzékeny Ca-hiányos talajokat.

Shewchuk (1982) Kanadában a meghatározó nedves ülepedéssel 1-24 $\mathrm{kg} / \mathrm{ha} /$ év S és 0-11 kg/ha/év $\mathrm{NO}_{3}-\mathrm{N}$ mennyiségeket azonosított az ország eltérô vidékein. Véleménye szerint szükséges bóvíteni a monitoring rendszert és kiterjedtebb víz és hó mintavételezést folytatni. Enélkül nem leszünk képesek a hatósági emissziós határértékeket megbízhatóan kijelölni. Odén (1979) Dél-Svédországban $25 \mathrm{~kg} / \mathrm{ha}$ /év S ülepedéssel számolt, melyet az ottani elsavanyodó élôvizekre rendkívül veszélyesnek ítélt. Megemlítjük, hogy a S-emisszió drasztikus visszafogása nyomán északnyugat Európa számos vidékén ma már a talajok, illetve növények S-hiányról, illetve a S-trágyázás hatékonyságáról esik szó.

A csapadékvíz biztosítja a légkör tisztulását, kémiai összetétele tükrözi annak szennyezettségi fokát. Mint természetes tápanyagforrás, szerepet játszik a talaj-növény rendszer elemforgalmában. Jelentőségének megítélése tehát egyaránt fontos lehet agronómiai, talajtani - agrokémiai és környezetvédelmi szempontból. Az összetevők változhatnak. Ipari körzetek, városok, sûrún lakott vidékek közelségében más lesz a csapadékvíz összetétele, mint a mezôgazdasági területek, bolygatatlan erdők, érintetlen sztyeppek vagy az óceánok térségében. Tengerpartokon pl. kiugró lehet a $\mathrm{Cl}$ és $\mathrm{Na}$, részben a $\mathrm{N}, \mathrm{K}, \mathrm{S}, \mathrm{Mg}$ mennyisége. A humán aktivitás jellegéből adódóan bármely elem emissziója megnőhet.

Mivel a csapadékvíz összetétele rendkívüli mértékben ingadozhat, célszerú adatsorokkal dolgozni és óvatosan általánosítani. Nagy lehet a szennyezôdés veszélye a mérés folyamán, hiszen nyomelemek esetében $\mu \mathrm{g} / \mathrm{liter}$ koncentrációkkal dolgozunk. És éppen ilyen nyomelemek esetében ma már az emberi 
tevékenység játszik kulcsszerepet a regionális és globális légköri ciklusban. Az 1980-as évek adataira támaszkodva Nriagu és Pacyna (1988), illetve Nriagu (1989) úgy becsülte, hogy a légköri Pb 96, Cd 85, V 75, Zn 66, Ni 65, As 61, Hg és Sb 59, Cu 56, Mo 52, Se 42, Cr 41\%-a globálisan tekintve humán eredetú. Megállapították, hogy gyorsan halmozódnak a toxikus elemek a levegóben, vizekben, talajokban, illetve a tápláléklánc egészében. Mindez ismeretlen kockázatot jelent a jövố generáció számára.

A természetes/humán források arányát, illetve relatív hatását az úgynevezett dúsulási tényező (EF: enrichment factor) jelzi. A döntően talajeredetû elemek dúsulási tényezője közelít az 1-hez, a talajösszetételekhez, általában kisebb, mint 5. A légszennyezô elemeké e feletti. A száraz felszín mállásából származó talajalkotó elemek általában nagyobb részecskéket alkotnak, gyorsabban kiülepednek. A légszennyezó mikroelemek részben az $1 \mu \mathrm{m}$-nél kisebb sugarú aeroszolhoz kötődnek és a mozgásukat a hosszútávú transzport jellemzi (Mészáros et al. 1993).

Hazánkban Horváth és Mészáros (1984), valamint Molnár et al. (1993) végeztek átfogó méréseket. A háttérszennyezést reprezentáló K-pusztán a Si, Al, Ti, Fe, Ca, K talajalkotók érdemi, 5 feletti dúsulást nem mutattak. A S és As 2-3ezerszeres, $\mathrm{Pb}$ és $\mathrm{Zn}$ több-százszoros dúsulást, szennyezést mutatott. Budapest belvárosában 20-szoros volt az aeroszolban mért $\mathrm{Pb}$ mennyisége a háttérszennyezéshez, illetve 8000-szeres a normál talajösszetételhez képest. Hasonlóan erős légszennyezést találtak a S, Zn, As esetében. A Cl 380, Cu 160 dúsulási együtthatóval volt jellemezhetô.

Ross (1987) az egyes szennyező elemeknél Dél-Svédországban az alábbi dúsulási együtthatókat állapított meg a normál talajösszetételhez viszonyítva: Cd 500-2600, Pb 450-1600, Zn 200-1400, Cu 28-110. Szerinte a szennyezés nagy része Európából származik, nem a helyi emisszióra vezethetó vissza. Erre utal, hogy szoros a korreláció a $\mathrm{Cd}, \mathrm{Zn}, \mathrm{Pb}^{\mathrm{s}}$ a $\mathrm{SO}_{4}{ }^{2-}$ között, mely a hosszú távú transzportot tükrözi. Gray et al. (2003) Új-Zéland legelôin 2 éven át mérték a légköri ülepedést. A csapadék mennyisége $734-1495$ mm között ingadozott, a vezetôképesség 31-112 $\mathrm{S}$ /cm volt. A Zn 1025, Cu 35, Cr 28, Pb 23, Cd 0,2 g/ha/év átlagos terhelést mutatott. Szerzôk a kiugróan nagy Zn-terhelés feltételezett okaként a háztetôk gyakori galvanizált ZnO-os lemezborítására utaltak.

Bozó és Horváth (1992) szerint az ülepedés, az $\mathrm{Pb}, \mathrm{Zn}$, Cd depoziciója a hazai kibocsátást, az emissziót meghaladta az 1984-1988. években. Fôként a „Fekete háromszög”, a cseh-lengyel-NDK sziléziai iparvidék exportálta a ne- 
hézfém-terhelést az É-Ny-i szelekkel. Felső-Szilézia legszennyezettebb része Katowice térsége, ahol 14 acélmú és olvasztó, 55 érc- és szénbánya, valamint 23 erômú múködött. Itt összpontosult az ország széntermelésének 98\%-a, valamint az Pb és Zn előállítás 100\%-a. Az összes kiülepedés maximuma elérte a $7,8 \mathrm{~kg} / \mathrm{ha} /$ év Pb, illetve 369 g/ha/év Cd mennyiséget. A talajok, növények erôsen szennyezôdtek, a térség egy része mezőgazdasági hasznosításra alkalmatlanná vált (Kucharski et al. 1994).

Az extrém szennyezés példája Lengyelországban a Pulawy városa melletti N mútrágyagyár, mely 1966 óta évente 20 ezer t N-emissziós forrást jelentett. A légkörbe jutó $\mathrm{NO}_{\mathrm{x}}, \mathrm{NH}_{3}, \mathrm{NH}_{4} \mathrm{NO}_{3}$ és karbamid gőz/por terhelés nyomán közel 1000 ha erdő pusztult el a gyár közvetlen közelében. A kihelyezett liziméteres kísérletekben a növények a N-t kizárólag a levegőból nyerik. A 0-10 cm feltalajban az $\mathrm{NH}_{4}-\mathrm{N}$ maximuma elérte a $293 \mathrm{~kg} / \mathrm{ha}, \mathrm{NO}_{3}-\mathrm{N}$ a $248 \mathrm{~kg} / \mathrm{ha}$ mennyiséget. Április és szeptember közötti tenyészidő alatt a legszennyezettebb pontokon $133 \mathrm{~kg} /$ ha $\mathrm{NH}_{4}-\mathrm{N}+118 \mathrm{~kg} /$ ha $\mathrm{NO}_{3}-\mathrm{N}$ jutott a talajba csapadékkal. A kukorica és a füvek termése megtöbbszöröződött a kontrollhoz viszonyítva és a N-túltáplálást az igen erôs zöld szín is jelezte (Chojnaczki és Zorawska 1980).

Warda et al. (1980) szintén Lengyelországban, egy metallurgiai gyár körzetében lizimétereket helyeztek el szennyezetlen talajjal és 2 év után mérték az ülepedés hatását a talajban és a termesztett növényekben. A 0-15 cm talaj eredeti Zn-készlete 15-szörösére, Pb-tartalma 25-szörösösére, S-tartalma 2-szeresére nôtt. A 0,1 N EDTA oldható tartalmakban általában két nagyságrendbeli emelkedést regisztráltak. A földfeletti növényi hajtásban a Zn 40-szeres, Pb 24-szeres, S 6-szoros dúsulást jelzett a kontroll területhez viszonyítva. A talaj-és növényvizsgálat jó indikátora lehet a légköri szennyezésnek, állapítják meg a szerzôk. A gyár körzetében a mezőgazdasági tevékenység 1966. óta szünetel.

Mansfield és Freer-Smith (1981) vizsgálták a városi légszennyezés növényi növekedésre gyakorolt hatását Angliában. A növények fejlődése elsôsorban a levegô S-mentességével volt pozitív kapcsolatban. $\mathrm{A} \mathrm{SO}_{2}$ mérgezô hatása bizonyos koncentráció felett jelentkezik és függ a növényfajtól, expozíciós időtôl, valamint egyéb gázok jelenlététôl. A másodlagos szennyezők, mint az $\mathrm{O}_{3}, \mathrm{NO}_{\mathrm{x}}$, fotókémiai szmog anyagai, a gépkocsi kipufogógázok nem teljesen elégett szénhidrogén termékei szintén növelik a toxicitást. A városi levegóben a gépkocsiforgalom miatt a $\mathrm{NO}_{\mathrm{x}}$ is dúsul. Fontos utóbbiban a $\mathrm{NO}: \mathrm{NO}_{2}$ aránya, mert a $\mathrm{NO}_{2}$ erôs méreg. $\mathrm{A} \mathrm{SO}_{2}+\mathrm{NO}_{2}$ együttes hatása tartós fumigációnak minôsül 
télen, amikor a fútés szennyezó hatása is hozzáadódik a ködös, lecsökkent légcserével rendelkezô városi légrétegekhez. A városi levegőben tehát az egyedi gázok ( $\mathrm{SO}_{2}, \mathrm{NO}, \mathrm{NO}_{2}, \mathrm{O}_{3}$, stb) toxicitása is nőhet, mert hatásuk összeadódik, a mérgezóbb $\mathrm{NO}_{2}$ redukcióját a $\mathrm{SO}_{2}$ pedig gátolhatja.

A légköri terhelés jelentőségét országosan becsülve Anderson (1992) felállította Svédország mikroelem mérlegét az 1900-1990. évekre. Véleménye szerint a növénytermesztô gazdaságok talajai szegényednek $\mathrm{Zn}, \mathrm{Cu}, \mathrm{Mn}$ elemekben, míg az állattenyésztố üzemekben lassan gazdagodnak a takarmánykiegészítô $\mathrm{Zn}, \mathrm{Cu}$ és Mn só-terhelés miatt. Minden talajon nó az $\mathrm{Pb}, \mathrm{Cd}, \mathrm{Hg}$ elemek koncentrációja a légköri terhelés és a helyenkénti szennyvíziszap-kihelyezés nyomán. Az utóbbi változások kismérvúek, de nemkívánatosak. A növények Cd tartalma megkétszereződhetett a vizsgált 90 év alatt. A múvelt talajrétegben hígulási effektus érvényesülhetett, hisz a szántás mélysége a korábbi 15-20 cm-rôl 20-25 cm-re nôtt. Az erdő sérülékeny vékony feltalajában ugyanakkor helyenként az Pb-készlet 15 mg/kg-ról 60-65 mg/kg-ra emelkedett, több mint megháromszorozódott. Veszélyeztetettek az elsavanyodó élővizek. A jövőbeni cél csak a fenntarthatóság lehet, szögezi le a szerző.

Sager (2008) Ausztriában saját és irodalmi utalásokra támaszkodva a mikroelemek légköri ülepedését 1999-2000. években az alábbi átlagadatokkal jellemezte: Zn 308, Cu 110, Ni 30, Pb 24, Cr 12, Cd 2 g/ha/év. A mútrágyákkal okozott talajterheléssel összehasonlítva megállapítja, hogy a Cr és a V elemeknél a mútrágyák, míg az $\mathrm{Pb}$ és Zn elemeknél a légköri terhelés a meghatározó. Az As, Cd, Ni elemek esetében megközelítóen azonos forrást jelenthet a légköri depozíció és az alkalmazott mútrágyák elemszennyezettsége.

Magyarország mikroelem mérlegét az 1980-as évek adataira támaszkova Kádár (2005) kísérelte meg felállítani. Országos felmérések eredményei szerint múvelt talajaink nem szennyezettek mikroelemekkel, nehézfémekkel. Nemzetközi összehasonlításban alacsony ellátottságot mutatott a búza és a kukorica termóhelyek 55\%-a Zn, 39\%-a Cu, 31\%-a Mo, 25\%-a Mn és Co, 20\%-a Se elemek tekintetében (Sillampää 1990, Kádár 1995). A szennyezettebb ipari, városi és közlekedési környezetben ugyanakkor kimutatható volt a talajok és növények emelkedett $\mathrm{Zn}, \mathrm{Cu}$, Cd és részben Ni akkumulációja.

Mikroelem szennyezőkben leggazdagabbak a foszformútrágyák. Elemzéseink szerint (Kádár 1992) a hazai szuperfoszfát-gyártás alapanyagául szolgáló import Kóla-foszfátok általában egy nagyságrenddel több Ga, Mn, Sr, illetve egy nagyságrenddel kevesebb $\mathrm{Cd}, \mathrm{Cr}, \mathrm{Ni}, \mathrm{Zn}$ tartalommal rendelkeztek, mint 
az Észak-Afrikából származó nyersfoszfátok, melyeket Nyugat-Európa használt. Talajaink nem szennyeződtek a legveszélyesebbnek ítélt mérgezó elemmel, Cd-mal. Becsléseink szerint az 1980-as években, az intenzív mútrágyázás idején kb. 30 g As, 8 g Zn és Cu, 4-5 g Pb, 1-2 g Se, 0,8 g Cd és 0,4 g Ni terheléssel járt a mútrágyahasználat országosan ha-onként. A mútrágyázás nem minôsült érdemi szennyezőnek, részesedése 5-10\% volt az összes terhelésben. Kivételt ez alól az As jelentett szuperfoszfát formájában, mely az összes terhelés akár 2/3-át adhatta (1. táblázat).

\section{1. táblázat. Mezógazdaságilag múvelt talajok becsült mikroelem mérlegének} egyenlegei Magyarországon az 1980-as években, g/ha

(Kádár 2005)

\begin{tabular}{lrrrrrrr}
\hline \multicolumn{1}{c}{\begin{tabular}{c} 
Mérleg tételei \\
\multicolumn{1}{c}{ (1) }
\end{tabular}} & $\mathrm{Zn}$ & $\mathrm{Pb}$ & $\mathrm{Cu}$ & $\mathrm{Ni}$ & $\mathrm{As}$ & $\mathrm{Cd}$ & $\mathrm{Se}$ \\
\hline Mütrágyák (3) & 8 & 5 & 8 & $<1$ & 30 & 0,8 & 1,5 \\
Szerves trágyák (4) & 180 & 30 & 60 & 15 & 15 & 1,5 & 1,5 \\
Szennyvíziszapok (5) & 50 & 17 & 17 & 3 & 2 & 0,3 & 1,7 \\
Meszezóanyagok (6) & 2 & $<1$ & 1 & $<1$ & $<1$ & $<0,1$ & $<0,1$ \\
Melléktermékek (7) & 80 & 8 & 60 & 7 & $<1$ & 0,8 & 0,5 \\
Csapadék (8) & 200 & 70 & 24 & 15 & 1 & 5,0 & $* 1,0$ \\
Összesen (9) & 520 & 130 & 170 & 40 & 47 & 8,4 & 6,2 \\
\hline & Kiadás (10) & & & & & \\
\hline Növényi felvétel (11) & 200 & 10 & 100 & 10 & 1 & 1,0 & 1,0 \\
Kimosódás (12) & 20 & 10 & 5 & 5 & 4 & 1,0 & 0,5 \\
Elillanás (13) & - & 5 & - & - & 5 & - & 1,0 \\
Összesen (9) & 220 & 25 & 105 & 15 & 10 & 2,0 & 2,5 \\
Egyenleg (14) & +300 & +105 & +65 & +25 & +38 & $+6,4$ & $+3,7$ \\
\hline Bevétel a kiadás \%-ában (15) & 236 & 520 & 162 & 267 & 480 & 420 & 248 \\
\hline
\end{tabular}

*Szóbeli közlés: Molnár Ágnes, Veszprémi Egyetem Levegókémiai Csoport.

Table 1. Estimated microelement-balance in agricultural cultivated soils in Hungary in the 1980's, g/ha (In: Kádár 2005). (1) Balance items, (2) Input, (3) Mineral fertilizers, (4) Organic fertilizers, (5) Sewage sludge, (6) Liming materials, (7) By-products, (8) Precipitation, (9) Total, (10) Output, (11) Plant uptake, (12) Leaching, (13) Volatilisation, (14) Total balance, (15) Input \% compared to output. *Verbal information from Ágnes Molnár, Atmospheric chemistry group, University of Veszprém.

A szervestrágyázás jelentős terhelésnek bizonyult a $\mathrm{Zn}, \mathrm{Pb}, \mathrm{Cu}, \mathrm{Ni}$, As elemek tekintetében. Legnagyobb súllyal viszont a csapadékkal talajba jutó lég- 
köri terhelés növelte a bevételt a $\mathrm{Zn}, \mathrm{Pb}, \mathrm{Cd}$ és részben a Ni nehézfémek mérlegében. Az 1. táblázatban bemutatott eredmények szerint a vizsgált mikroelemek mérlege pozitív egyenleget mutatott. Az Pb és az As bevételt mintegy 5-szörösen, Cd 4-szeresen, Se 2,5-szeresen, Zn és Ni 1,5-szeresen haladta meg a kiadási oldalt. A helyzet azóta megváltozott. Az 1990-es éveket követôen közel 1/5-ére zuhant az Pb-terhelés az Pb-mentes benzin bevezetésével, illetve hasonló mértékben esett vissza az As-terhelés a szuperfoszfát mútrágyázás csökkenésével. A sziléziai „Fekete háromszög” $\mathrm{Pb}, \mathrm{Cd}, \mathrm{Zn}$ exportja is drasztikusan mérséklôdött a korábbi iparvidék átalakulása nyomán.

\section{Anyag és módszer}

A mintavételek az MTA TAKI két kísérleti telepén, a mezóföldi Nagyhörcsök és a Duna-Tisza közi Ôrbottyán termóhelyen folytak, ahol rendszeres csapadékméréseket végzünk immár fél évszázada. A csapadék mennyiségét az úgynevezett Hellmann-rendszerú csapadékmérôvel mérjük, melynek két fố része a bádogból készült felfogó edény és az üvegből készült mérôhenger. Az 1 m magasságban kihelyezett készüléket az általános meteorológiai gyakorlat szerint naponta egyszer, reggel 7 órakor ürítjük. A mérés $0,1 \mathrm{~mm}$ pontossággal történik. A szilárd halmazállapotú hó, dara, ónos esô, jégesố esetén a mérés az elôzetes megolvasztást követôen történik. A harmatot, deret, zúzmarát nem számítjuk csapadéknak.

A csapadékot hútôszekrényben tároltuk és havonta analizáltuk 26 tulajdonságra. Az ásványi elemek mérése ICP technikával történt. Meghatároztuk a csapadékvíz pH-ját, elektromos vezetóképességét, valamint a makro- és mikroelem tartalmát, illetve $\mathrm{NH}_{4}-\mathrm{N}$ és $\mathrm{NO}_{3}$-N koncentrációját. A csapadék menynyiségét az elemkoncentrációkkal szorozva számítottuk az elemhozamokat, tehát a kiülepedést. Megemlítjük, hogy a csapadékmérôbe nem csak az esô, hanem az aeroszol részecskék úgynevezett száraz ülepedése is juttathat különbözó anyagokat. Méréseink a nedves és száraz ülepedés együttes hatását tükrözik. Irodalmi adatok szerint azonban a száraz ülepedés részaránya az elemenként eltérô lehet és általában 5-10\% körüli, hibahatáron belül maradhat.

A csapadékmérô bádogból készült felfogó edényeinek esetleges szennyezô hatását külön is vizsgáltuk. Desztillált vizet az edényben 3 napon át állni hagytuk, és ezt követôen analizáltuk. Utána a 4 pH-jú desztillált vizet 3 napon át állni hagytuk az edényben, és ezt követôen elemeztük a savanyított desztillált vizet. 
A pH-t potenciometriásan, az elektromos vezetôképességet (EC) konduktometriásan az eredeti mintákból határoztuk meg. Szúrés a víz zavarosságától függôen finom pórusú szúrôpapíron vagy a 0,45 $\mu$ m pórusméretú baktériumszúroón történt. A szúrletből közvetlenül mértük a Ca, Mg, K, Na, B, S elemeket, valamint a karbonátot, hidrogénkarbonátot, kloridot, ammóniát, nitrátot és szükség szerint a szulfátot. Utóbbit csak akkor, ha a vízben szulfidokra utaló nyomokat tapasztaltunk és ezüstnitráttal ellenőriztük. Egyébként a ként mértük. A karbonátot, hidrogénkarbonátot acidimetriásan, szulfátot jodometriásan, kloridot argentometriásan, az ammóniát és a nitrátot Wagner-Parnas vízgőzdesztillációval, nitrátredukciót Dewarda ötvözettel végeztük (MSZ ISO 5667-10).

Ezt követôen a szúrletet az eredeti térfogat 1/4-re bepároltuk salétromsavas savanyítás után a mikroelemek vizsgálata céljából. A 4×-es töményítés eredményeképpen 4 ×-es kimutatási határjavulást lehet elérni. Kimutatási határok az alábbiak szerint alakultak a mikroelemeknél: Cd, Co, Fe, Mo 0,1-0,2 $\mu \mathrm{g} / \mathrm{l}$; Cr

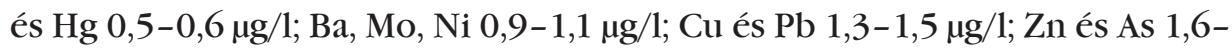

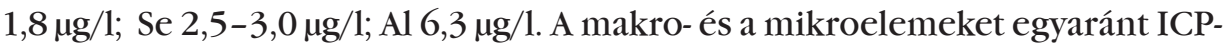
OES készülékkel határoztuk meg. Kimutatási határ a makroelemekre: K, P és

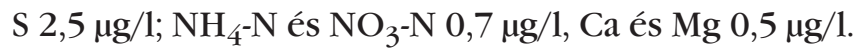

\section{Eredmények megvitatása}

A csapadék mennyisége, vezetőképessége, pH, valamint az elemkoncentrációk és elemhozamok közötti kapcsolatokat a 2. táblázatban tanulmányozhatjuk. A táblázat a Duna-Tisza közi Ôrbottyán Kísérleti Telep 2007. I. félévének adatait mutatja be havi bontásban. Látható, hogy a minimális $4 \mathrm{~mm}$ április havi csapadékösszeghez köthetô a maximális vezetőképesség, $\mathrm{pH}, \mathrm{NH}_{4}-\mathrm{N}, \mathrm{Na}$ és $\mathrm{K}$ koncentráció, illetve a $\mathrm{NO}_{3}-\mathrm{N}$ hiánya. A maximális elemhozamot ugyanakkor a leginkább csapadékos május és június biztosította. Erôsen savanyú a márciusi csapadék 4,2 értékkel. Megfigyelhető, hogy az 5 alatti pH értékeknél általában kifejezett, 3-5-szörös a salétromsavat képezó $\mathrm{NO}_{3}-\mathrm{N}$ túlsúlya a pH-növelő $\mathrm{NH}_{4}$ - $\mathrm{N}$ mennyiségéhez viszonyítva. $\mathrm{A} \mathrm{NO}_{3}-\mathrm{N}$ túlsúlya a N-hozamban is tükrözôdik. A vizsgált félév alatt összesen $14 \mathrm{~kg} \mathrm{~N}, 10 \mathrm{~kg} \mathrm{Ca}$, illetve 2-3 kg Na és K kiülepedés történt ha-ra vetítve. A S mennyisége csak nyomokban volt kimutatható. A II. félévben ilyen látványos és tanulságos különbségek nem alakultak ki sem a csapadékvíz havi mennyiségében, sem annak összetételében, így részletes taglalásoktól eltekintünk. 
2. táblázat. A havi csapadék mennyisége, vezetőképessége, $\mathrm{pH}, \mathrm{Ca}, \mathrm{NH}_{4}-\mathrm{N}, \mathrm{NO}_{3}{ }^{-\mathrm{N}}, \mathrm{S}$,

Na és K koncentrációk, illetve az elemhozamok alakulása 2007-ben

(Duna-Tisza köze, karbonátos homoktalaj, Ôrbottyán)

\begin{tabular}{|c|c|c|c|c|c|c|c|c|c|}
\hline \multirow{2}{*}{$\begin{array}{c}\text { Hónapok } \\
\text { 2007-ben } \\
\text { (1) }\end{array}$} & \multirow{2}{*}{$\begin{array}{c}\text { Csapa- } \\
\text { dék } \\
\mathrm{mm} \\
(2)\end{array}$} & \multirow{2}{*}{$\begin{array}{l}\text { Vezető- } \\
\text { képesség } \\
\mu \mathrm{S} / \mathrm{cm} \\
\text { (3) }\end{array}$} & \multirow{2}{*}{$\mathrm{pH}$} & $\mathrm{Ca}$ & $\mathrm{NH}_{4}-\mathrm{N}$ & $\mathrm{NO}_{3}-\mathrm{N}$ & $\mathrm{S}$ & $\mathrm{Na}$ & K \\
\hline & & & & \multicolumn{6}{|c|}{$\begin{array}{c}\text { Koncentráció, mg/l } \\
(4)\end{array}$} \\
\hline I. & 31 & 62 & 4,5 & 3,6 & 0,7 & 4,0 & ny & 1,1 & 1,1 \\
\hline II. & 46 & 54 & 4,8 & 3,4 & 1,1 & 3,6 & ny & 1,1 & 0,9 \\
\hline III. & 39 & 78 & 4,2 & 4,4 & 0,8 & 4,0 & ny & 0,7 & 0,7 \\
\hline IV. & 4 & 140 & 7,2 & 4,7 & 11,6 & 0,0 & ny & 1,2 & 3,1 \\
\hline V. & 58 & 71 & 6,9 & 1,9 & 5,5 & 1,7 & ny & 1,2 & 1,2 \\
\hline VI. & 61 & 86 & 4,5 & 7,7 & 0,7 & 5,8 & ny & 0,9 & 2,0 \\
\hline
\end{tabular}

\begin{tabular}{|c|c|c|c|c|c|c|c|c|c|}
\hline \multirow{2}{*}{$\begin{array}{c}\text { Hónapok } \\
\text { 2007-ben } \\
\text { (1) }\end{array}$} & \multirow{2}{*}{$\begin{array}{l}\text { Csapa- } \\
\text { dék } \\
\mathrm{mm} \\
(2)\end{array}$} & \multirow{2}{*}{$\begin{array}{l}\text { Vezető- } \\
\text { képesség } \\
\mu \mathrm{S} / \mathrm{cm} \\
\text { (3) }\end{array}$} & \multirow{2}{*}{$\mathrm{pH}$} & $\mathrm{Ca}$ & $\mathrm{NH}_{4}-\mathrm{N}$ & $\mathrm{NO}_{3}-\mathrm{N}$ & $\mathrm{S}$ & $\mathrm{Na}$ & K \\
\hline & & & & \multicolumn{6}{|c|}{$\begin{array}{c}\text { Elemhozam, } \mathrm{kg} / \mathrm{ha} \\
(5)\end{array}$} \\
\hline I. & 31 & 62 & 4,5 & 1,1 & 0,2 & 1,2 & ny & 0,3 & 0,3 \\
\hline II. & 46 & 54 & 4,8 & 1,5 & 0,5 & 1,6 & ny & 0,5 & 0,4 \\
\hline III. & 39 & 78 & 4,2 & 1,7 & 0,3 & 1,6 & ny & 0,3 & 0,3 \\
\hline IV. & 4 & 140 & 7,2 & 0,2 & 0,5 & 0,0 & ny & 0,0 & 0,1 \\
\hline V. & 58 & 71 & 6,9 & 1,1 & 3,2 & 1,0 & ny & 0,7 & 0,7 \\
\hline VI. & 61 & 86 & 4,5 & 4,7 & 0,4 & 3,6 & ny & 0,5 & 1,2 \\
\hline Össz. (6) & 239 & - & - & 10,3 & 5,2 & 9,0 & - & 2,4 & 3,1 \\
\hline
\end{tabular}

Table 2. Amount, electrical conductivity, $\mathrm{pH}$, concentrations of $\mathrm{Ca}, \mathrm{NH}_{4}-\mathrm{N}, \mathrm{NO}_{3}-\mathrm{N}, \mathrm{S}, \mathrm{Na}$ and $\mathrm{K}$ of the monthly precipitation as well as element yield in 2007 (Danube-Tisza mid region, calcareous sandy soil, Órbottyán). (1) Months in 2007, (2) Precipitation, (3) Conductivity, (4) Concentration, (5) Element yield, (6) Total.

A 3. táblázatban a mezóföldi telepünk 2007. évi eredményeit ismertetjük. Április csapadékmentes volt. A vezetôképesség, $\mathrm{pH}$, valamint a Ca, $\mathrm{NH}_{4}-\mathrm{N}, \mathrm{S}$, K elemkoncentrációk maximumai a nyári, júliusi aszályos hónaphoz köthetôk Az elemhozamok tekintetében ( $\mathrm{Ca}, \mathrm{NH}_{4}-\mathrm{N}, \mathrm{S}, \mathrm{K}$ ) viszont a 84 mm-rel rendelkezó május bizonyult a legproduktívabbnak. Úgy túnik a téli hónapok elemhozamokban szegényebbek. A pH értéke egész évben 5 felett maradt. $\mathrm{Az} \mathrm{NH}_{4}-\mathrm{N}$ túlsúlya az év átlagát tekintve kereken 6-szoros a $\mathrm{NO}_{3}-\mathrm{N}$ mennyiségéhez képest. $\mathrm{A}$ melegebb május, június, július hónapokban az $\mathrm{NH}_{4}-\mathrm{N}$ koncentrációja 10-20- 
3. táblázat. A csapadék mennyisége, vezetôképessége, $\mathrm{pH}, \mathrm{Ca}, \mathrm{NH}_{4}-\mathrm{N}, \mathrm{NO}_{3}-\mathrm{N}, \mathrm{S}, \mathrm{Na}$ és K koncentrációk, illetve az elemhozamok alakulása 2007-ben (Mészlepedékes csernozjom vályogtalaj, Nagyhörcsök, Mezöföld)

\begin{tabular}{|c|c|c|c|c|c|c|c|c|c|}
\hline \multirow{2}{*}{ 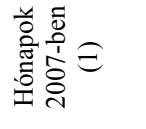 } & \multirow{2}{*}{ 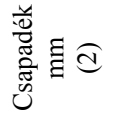 } & \multirow{2}{*}{ 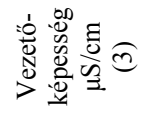 } & \multirow{2}{*}{$\mathrm{pH}$} & $\mathrm{Ca}$ & $\mathrm{NH}_{4}-\mathrm{N}$ & $\mathrm{NO}_{3}-\mathrm{N}$ & $\mathrm{S}$ & $\mathrm{Na}$ & $\mathrm{K}$ \\
\hline & & & & \multicolumn{6}{|c|}{ Koncentráció, mg/l (4) } \\
\hline I. & 18 & 105 & 5,8 & 3,6 & 2,6 & 1,3 & 3,0 & 7,9 & 1,4 \\
\hline II. & 38 & 39 & 5,1 & 2,2 & 1,9 & 0,9 & 1,1 & 1,9 & 0,5 \\
\hline III. & 36 & 57 & 5,3 & 1,1 & 3,1 & 1,7 & 2,3 & 1,1 & 1,4 \\
\hline IV. & - & - & - & - & - & - & - & - & - \\
\hline V. & 84 & 151 & 6,2 & 2,7 & 11,9 & 0,9 & 2,5 & 1,6 & 5,2 \\
\hline VI. & 45 & 131 & 6,0 & 1,4 & 12,4 & 0,6 & 1,3 & 0,8 & 2,5 \\
\hline VII. & 22 & 220 & 7,0 & 4,5 & 15,0 & 1,3 & 4,4 & 4,3 & 11,0 \\
\hline VIII. & 97 & 56 & 6,6 & 0,9 & 3,3 & 1,0 & 1,2 & 1,1 & 1,4 \\
\hline IX. & 36 & 51 & 5,6 & 0,9 & 3,0 & 1,0 & 1,1 & 1,0 & 1,2 \\
\hline $\mathrm{X}$. & 52 & 77 & 5,8 & 1,6 & 5,0 & 1,0 & 2,6 & 0,7 & 2,7 \\
\hline XI. & 61 & 51 & 5,7 & 0,9 & 3,3 & 0,7 & 1,1 & 0,6 & 1,6 \\
\hline XII. & 59 & 29 & 5,6 & 0,5 & 1,4 & 0,6 & 0,6 & 1,3 & 0,3 \\
\hline \multirow{2}{*}{ 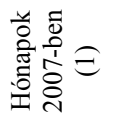 } & \multirow{2}{*}{ 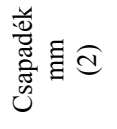 } & \multirow{2}{*}{ 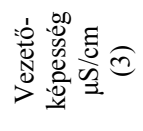 } & \multirow{2}{*}{$\mathrm{pH}$} & $\mathrm{Ca}$ & $\mathrm{NH}_{4}-\mathrm{N}$ & $\mathrm{NO}_{3}-\mathrm{N}$ & $\mathrm{S}$ & $\mathrm{Na}$ & K \\
\hline & & & & \multicolumn{6}{|c|}{ Elemhozam, kg/ha (5) } \\
\hline I. & 18 & 105 & 5,8 & 0,6 & 0,5 & 0,2 & 0,5 & 1,4 & 0,2 \\
\hline II. & 38 & 39 & 5,1 & 0,8 & 0,7 & 0,3 & 0,4 & 0,7 & 0,2 \\
\hline III. & 36 & 57 & 5,3 & 0,4 & 1,1 & 0,6 & 0,8 & 0,4 & 0,5 \\
\hline IV. & - & - & - & - & - & - & - & - & - \\
\hline V. & 84 & 151 & 6,2 & 2,3 & 10,0 & 0,7 & 2,1 & 1,3 & 4,4 \\
\hline VI. & 45 & 131 & 6,0 & 0,6 & 5,6 & 0,3 & 0,6 & 0,4 & 1,1 \\
\hline VII. & 22 & 220 & 7,0 & 1,0 & 3,3 & 0,3 & 1,0 & 0,9 & 2,4 \\
\hline VIII. & 97 & 56 & 6,6 & 0,9 & 3,2 & 1,0 & 1,2 & 1,1 & 1,3 \\
\hline IX. & 36 & 51 & 5,6 & 0,3 & 1,1 & 0,4 & 0,4 & 0,4 & 0,4 \\
\hline $\mathrm{X}$. & 52 & 77 & 5,8 & 0,8 & 2,6 & 0,5 & 1,4 & 0,4 & 1,4 \\
\hline XI. & 61 & 51 & 5,7 & 0,6 & 2,0 & 0,4 & 0,7 & 0,4 & 1,0 \\
\hline XII. & 59 & 29 & 5,6 & 0,3 & 0,8 & 0,3 & 0,4 & 0,7 & 0,2 \\
\hline Év össz. (6) & 548 & - & - & 8,7 & 30,9 & 5,1 & 9,5 & 8,1 & 13,2 \\
\hline
\end{tabular}

Megjegyzés: április csapadékmentes hónap volt. A vezetôképesség éves átlagban $94 \mu \mathrm{S} / \mathrm{cm}$, a pH 5,8 volt.

Table 3. Amount, electrical conductivity, $\mathrm{pH}$, concentrations of $\mathrm{Ca}, \mathrm{NH}_{4}-\mathrm{N}, \mathrm{NO}_{3}-\mathrm{N}, \mathrm{S}, \mathrm{Na}$ and $\mathrm{K}$ of the monthly precipitation as well as element yield in 2007 (Calcareous chernozem loamy soil, Nagyhörcsök, Mezőföld region). (1) Months in 2007, (2) Precipitation, (3) Conductivity, (4) Concentration, (5) Element yield, (6) Yearly. Note: No precipitation occured in April. 
szorosa a $\mathrm{NO}_{3}$-N koncentrációjának, decemberre ez az arány 2-2,5-szeresére szúkül.

Az ammónia kibocsátása 1980 és 2000 között 60\%-kal csökkent hazánkban. A kibocsátás zöme, 94-98\%-a mezőgazdasági eredetú. Forrásai a szervestrágyázás, N-mútrágyázás, állattartó telepek, valamint a kommunális szennyvizek és szeméttelepek (KSH 2003a). Nálunk a visszaesés mögött döntôen a N-mútrágyázás, állattenyésztés és a szervestrágyázás 1990 óta bekövetkezett csökkenése áll. Északnyugat Európa 1990 óta intézkedéseket hozott a légköri szennyezés $\left(\mathrm{SO}_{2}, \mathrm{NO}_{\mathrm{x}}, \mathrm{NH}_{3}\right)$ mérséklésére. Így pl. Hollandia is korlátozta az állatsúrúséget, bevezette az istállók levegójének szúrését, előírta a trágyalé közvetlen injektálását a talajba, a szerves trágya adagját maximálta és kijuttatását csak vegetációs idôben engedélyezi. Közbülsô idôszakban az istállótrágya/trágyalé zárt, fedett helyen tárolható (Boxman et al. 2008).

Ismeretes, hogy a mezőföldi telepünkhöz hasonló karbonátos talajokon az $\mathrm{NH}_{4} \mathrm{~N}$ formát tartalmazó $\mathrm{N}$-mútrágya jelentôs ammónia veszteséget szenvedhet. A telep mellett szarvasmarha hízlalása, tenyésztése is folyik. A környezó mezőgazdasági múvelt talajok $\mathrm{NH}_{3}$ emissziója szintén jelentős lehet a tavaszi/nyári idôszakban, amikor a baktériumok tevékenysége intenzív a jól szellózött humuszos meszes csernozjomokon. A talajfelszín tehát döntô emittáló faktor az emberi, gazdálkodási tevékenységgel együtt. A keleti irányból érkezố szelek Dunaújváros és a kôolajfinomítók, a nyugati irányból érkezôk pedig Székesfehérvár és Veszprém légszenynyezô hatását tükrözhetik esetenként, melyre főként a kiülepedő $S$ utalhat.

2008. I. félévében mért adatok szerint a csapadékvíz pH-ja folyamatosan nőtt január és július között. Januárban viszonylag kicsi a $\mathrm{NH}_{4}-\mathrm{N}$ és K lúgosító kationok koncentrációja, viszont jelentôs a savanyító $\mathrm{NO}_{3}-\mathrm{N}$ és $\mathrm{S}$ mennyisége az egész vizsgált félévben. Júniusra a meghatározó Ca kiülepedés 13-szorosára, az $\mathrm{NH}_{4}-\mathrm{N}$ kiülepedése 45-szörösére ugrott, miközben a $\mathrm{NO}_{3}-\mathrm{N}$ hozama érdemben nem változott. A S mennyisége is többszörösére emelkedett ezzel együtt, így a csapadékvíz pH-ja júniusban is 6 alatt maradt. A csapadék mennyisége extrém módon ingadozott és nem mutatott egyértelmú összefüggést a vezetôképességgel vagy a pH-értékkel (4. táblázat).

A 2005-2008. között mért légköri talajterhelés mértékérôl, illetve jellemzôiirôl az 5. táblázat nyújt áttekintést félévenkénti bontásban a vizsgált 26 paraméterre. Duna-Tisza közén található Ốrbottyán Kísérleti Telepünkön 2006. február és március hónapok csapadékában egy nagyságrenddel ugrott meg a $\mathrm{Ca}, \mathrm{Mg}, \mathrm{Na}, \mathrm{Sr}$ koncentrációja. Emellett nagy $\mathrm{NH}_{4} \mathrm{~N}, \mathrm{~S}$ és $\mathrm{Zn}$ ülepedést is re- 
4. táblázat. A havi csapadékösszeg, vezetőképesség, $\mathrm{pH}, \mathrm{Ca}, \mathrm{NH}_{4}-\mathrm{N}, \mathrm{NO}_{3}-\mathrm{N}, \mathrm{S}, \mathrm{Na}$ és $\mathrm{K}$ koncentrációk, illetve az elemhozamok 2008-ban

(Mezöföld, mészlepedékes csernozjom vályogtalaj, Nagyhörcsök)

\begin{tabular}{|c|c|c|c|c|c|c|c|c|c|}
\hline \multirow{2}{*}{$\begin{array}{c}\text { Hónapok } \\
\text { 2008-ban } \\
\text { (1) }\end{array}$} & \multirow{2}{*}{$\begin{array}{c}\text { Csapa- } \\
\text { dék } \\
\mathrm{mm} \\
(2) \\
\end{array}$} & \multirow{2}{*}{$\begin{array}{c}\text { Vezetö- } \\
\text { képesség } \\
\mu \mathrm{S} / \mathrm{cm} \\
(3)\end{array}$} & \multirow[b]{2}{*}{$\mathrm{pH}$} & $\mathrm{Ca}$ & $\mathrm{NH}_{4}-\mathrm{N}$ & $\mathrm{NO}_{3}-\mathrm{N}$ & $\mathrm{S}$ & $\mathrm{Na}$ & K \\
\hline & & & & \multicolumn{6}{|c|}{$\begin{array}{c}\text { Koncentráció, mg/1 } \\
\text { (4) }\end{array}$} \\
\hline I. & 11 & 79 & 4,8 & 3,0 & 3,1 & 1,7 & 9,9 & 0,7 & 0,5 \\
\hline II. & 4 & 94 & 5,0 & 2,5 & 4,8 & 1,8 & 10,0 & ny & ny \\
\hline III. & 50 & 79 & 5,4 & 1,5 & 3,3 & 0,9 & 6,4 & ny & 2,6 \\
\hline IV. & 18 & 288 & 5,6 & 7,4 & 21,3 & 2,1 & 11,7 & ny & 10,0 \\
\hline V. & 30 & 321 & 5,7 & 4,8 & 30,2 & 1,1 & 11,0 & ny & 6,2 \\
\hline VI. & 82 & 190 & 5,9 & 4,8 & 16,7 & 0,7 & 7,4 & ny & 2,8 \\
\hline \multirow{2}{*}{$\begin{array}{c}\text { Hónapok } \\
\text { 2008-ban } \\
\text { (1) }\end{array}$} & \multirow{2}{*}{$\begin{array}{l}\text { Csapa- } \\
\text { dék } \\
\text { mm } \\
(2)\end{array}$} & \multirow{2}{*}{$\begin{array}{l}\text { Vezető- } \\
\text { képesség } \\
\mu \mathrm{S} / \mathrm{cm} \\
\text { (3) }\end{array}$} & \multirow[b]{2}{*}{$\mathrm{pH}$} & $\mathrm{Ca}$ & $\mathrm{NH}_{4}-\mathrm{N}$ & $\mathrm{NO}_{3}-\mathrm{N}$ & $\mathrm{S}$ & $\mathrm{Na}$ & K \\
\hline & & & & \multicolumn{6}{|c|}{$\begin{array}{c}\text { Elemhozam, } \mathrm{kg} / \mathrm{ha} \\
(5)\end{array}$} \\
\hline I. & 11 & 79 & 4,8 & 0,3 & 0,3 & 0,2 & 1,1 & 0,1 & 0,1 \\
\hline II. & 4 & 94 & 5,0 & 0,1 & 0,2 & 0,1 & 0,4 & 0,0 & 0,0 \\
\hline III. & 50 & 79 & 5,4 & 0,8 & 1,6 & 0,4 & 3,2 & 0,0 & 1,3 \\
\hline IV. & 18 & 288 & 5,6 & 1,3 & 3,8 & 0,4 & 2,1 & 0,0 & 1,8 \\
\hline V. & 30 & 321 & 5,7 & 1,5 & 9,1 & 0,3 & 3,3 & 0,0 & 1,9 \\
\hline VI. & 82 & 190 & 5,9 & 3,9 & 13,7 & 0,6 & 6,0 & 0,0 & 2,3 \\
\hline Össz. (6) & 195 & - & - & 7,9 & 28,8 & 2,0 & 16,1 & 0,1 & 7,4 \\
\hline
\end{tabular}

ny: nyomokban

Table 4. Amount, electrical conductivity, $\mathrm{pH}$, concentrations of $\mathrm{Ca}, \mathrm{NH}_{4}-\mathrm{N}, \mathrm{NO}_{3}-\mathrm{N}, \mathrm{S}, \mathrm{Na}$ and $\mathrm{K}$ of the monthly precipitation as well as element yield in 2008 (Calcareous chernozem loamy soil, Nagyhörcsök, Mezőföld region). (1) Months in 2008, (2) Precipitation, (3) Conductivity, (4) Concentration, (5) Element yield, (6) Total. Ny: not detectable.

gisztráltunk. Mindez visszavezethetô volt a Váci Cementgyár emissziójára és a kedvezôtlen szélirányra. A pH elérte a 7,0 értéket, elektromos vezetôképesség pedig közelített a $2000 \mu \mathrm{S} / \mathrm{cm}$ értékhez. Az éves elemhozamok tekintélyes mennyiségnek adódtak: $60 \mathrm{~kg} / \mathrm{ha} \mathrm{Ca} ; 48 \mathrm{~kg} / \mathrm{ha} \mathrm{N} ; 21 \mathrm{~kg} / \mathrm{ha} \mathrm{S} ; 16 \mathrm{~kg} / \mathrm{ha} \mathrm{K}$ és Mg; $13 \mathrm{~kg} \mathrm{Na} ; 5-6$ kg/ha P. A mikroelemek közül kiemelhetố a Zn 1391 g/ha; Sr 202 g/ha; Cu 153 g/ha; Pb 7 g/ha; As 4 g/ha; Cr 3 g/ha mennyiséggel. 


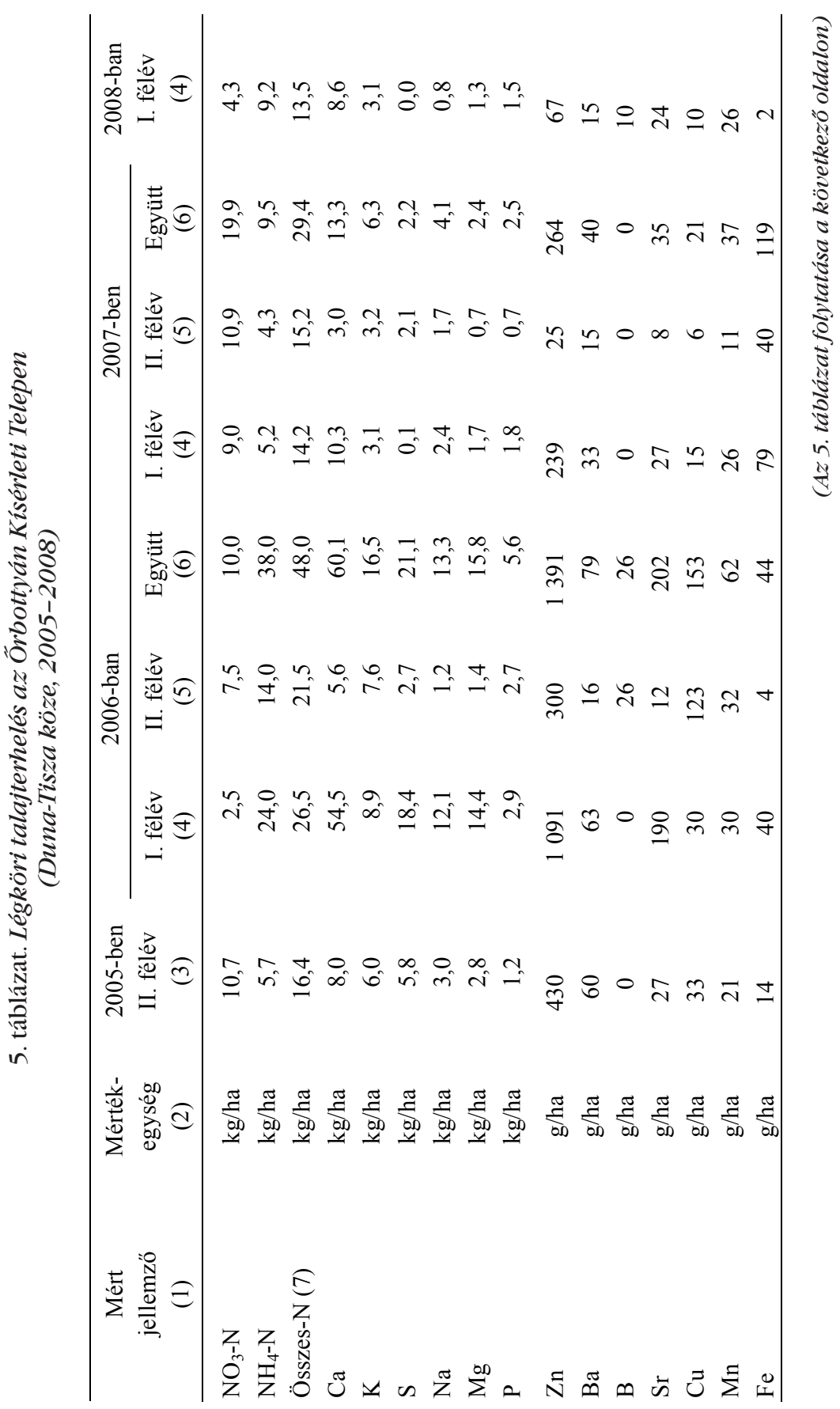




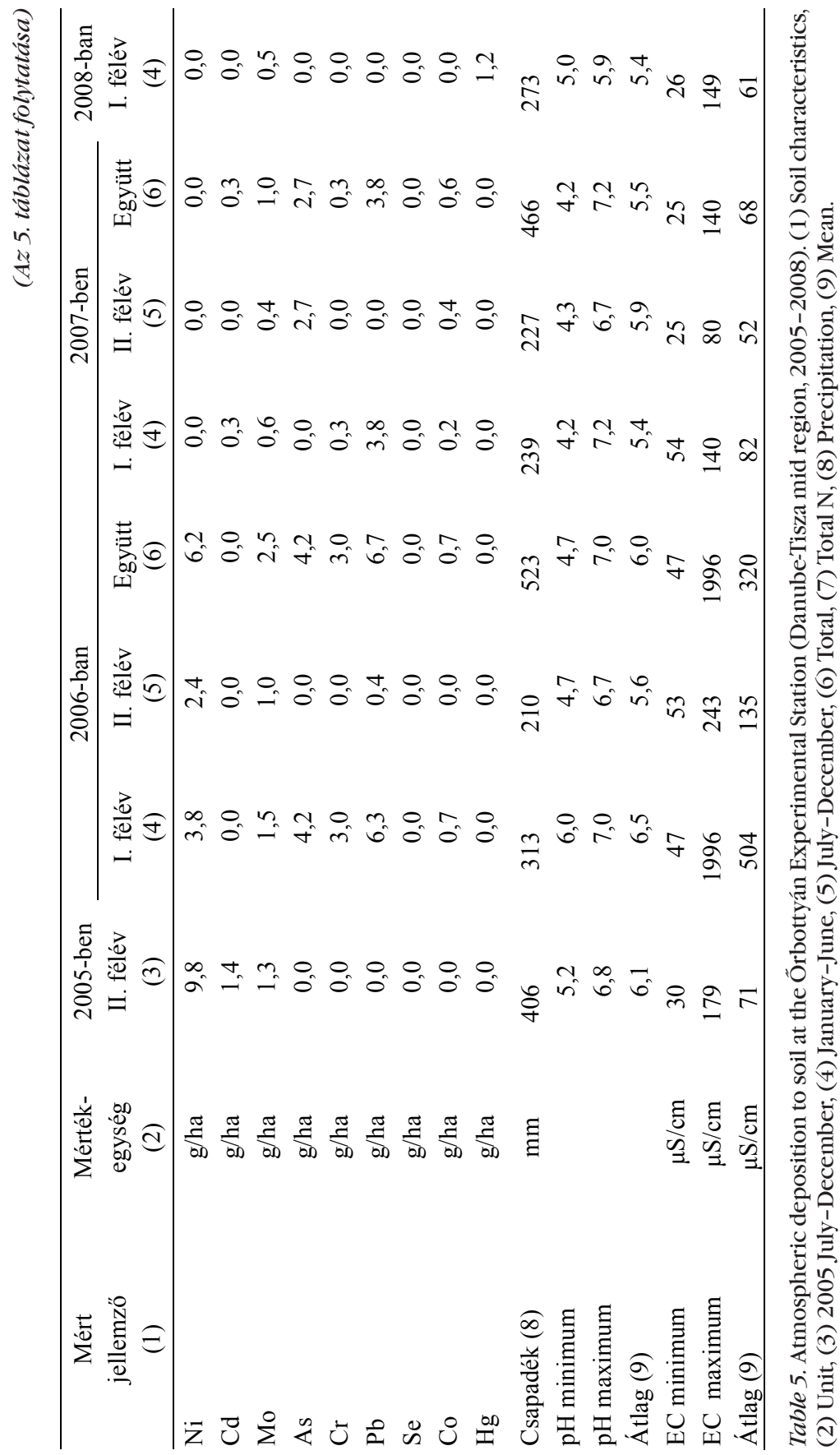


Ez a termőhely N, P és K elemekben egyaránt szegény. Agronómiai szempontból fontos az évente talajt gazdagító $25-50 \mathrm{~kg} / \mathrm{ha}$ körülire becsülhetô N-depozició, valamint 6-10 kg/ha K, illetve 2-4 kg/ha P ülepedése évente. Az 1960 óta folyó „örökrozs” mútrágyázási kísérletünkben a PK kezelések termése növekvő, mely korábbi véleményünk szerint is a légköri N-ülepedésre vezethetô vissza (Kádár et al. 1984, Lásztity et al. 1993). Szárazabb, kedvezótlenebb években a kalászosok szemtermése általában $2 \mathrm{t} / \mathrm{ha}$ alatt marad, N-hatásokat nem kapunk. A talaj N-szolgáltatását ilyenkor a légköri $\mathrm{N}$ ülepedése biztosíthatja. A mikroelemek közül a Zn és a Cu utánpótlása figyelemre méltó, hiszen ezen a $\mathrm{Zn}$ és Cu elemekkel rosszul ellátott termőhelyeken a légköri ülepedés teljes körúen fedezheti az itt elérhetô közepes termések Zn és Cu elemigényét. Az esetenkénti savanyú csapadék nemkívánatos hatását a légköri $\mathrm{Ca}, \mathrm{Mg}, \mathrm{Na}$ ellensúlyozhatja.

A 6. táblázat a mezőföldi kísérleti telep légköri talajterhelésérôl informál. Megállapítható, hogy az összes éves N-terhelés a $36 \mathrm{~kg} / \mathrm{ha}$ mennyiséget is elérheti. Általában meghatározó az $\mathrm{NH}_{4}-\mathrm{N}$ túlsúlya, mely a $\mathrm{NO}_{3}-\mathrm{N}$ mennyiségéhez képest 3-14-szeres lehet. A makroelemeket tekintve a K 13-14 kg/ha; S 6-16 $\mathrm{kg} / \mathrm{ha} ; \mathrm{Na}$ 7-8 kg/ha; Ca 6-9 kg/ha; P 4-5 kg/ha; Mg 2-3 kg/ha éves maximumokkal jellemezhetô. Növényélettani, agronómiai szempontból jelentôs lehet a légköri makroelem-pótlás, amennyiben az oldható formában kihulló esszenciális elemek mint levéltrágyák teljeskörúen hasznosulhatnak ideális esetben.

Közepes, 10 t/ha légszáraz földfeletti termésú ôszi árpa, melynek kb. fele a szemtermés fele a melléktermés, ezen a talajon az alábbi elemmennyiséget építette be testébe: N 102 kg; K 133 kg; P és S 25 kg; Ca 24 kg; Mg 18 kg; Na 2 $\mathrm{kg} / \mathrm{ha}$ (Kádár 2003). A légköri terhelés tehát fedezhette volna a felvett $\mathrm{K} 10$; Mg 15; P 20; Ca és N 30; S 40 és a Na 350-400\%-át. Mivel kombájn betakarításnál a melléktermés a táblán marad és visszakerül a talajba, csak a szembe épült elemek kivont tömegével számolhatunk. Ebben az esetben a légköri tápelempótlás aránya megnó, hisz a szemtermésbe mindössze $30 \mathrm{~kg} \mathrm{~K} ; 20 \mathrm{~kg} \mathrm{P} ; 8 \mathrm{~kg}$ $\mathrm{Mg} ; 6 \mathrm{~kg} \mathrm{~S} ; 2 \mathrm{~kg}$ Ca és $240 \mathrm{~g}$ Na épült be. A légköri forrás fedezhetné a P 25, K 45\%-át, míg a S és Ca 100-300\%-át, a szembe épült Na mennyiségét pedig a légköri terhelés nagyságrenddel haladhatja meg.

Ami az esszenciális és egyéb mikroelemeket illeti, az 5 t/ha körüli ôszi árpa szemtermése 305 g Fe; 125 g Mn; 90 g Al; 60 g Zn; 15 g Cu; 10 g Sr és Ba; 9 g B; 5 g Se; 1-2 g Mo és Ni; 0,5 g Co és Cr elemet tartalmazott. Az Pb, Hg, Cd toxikus nehézfémek mennyisége $0,1 \mathrm{~g} /$ ha kimutatási határ alatt maradt. 


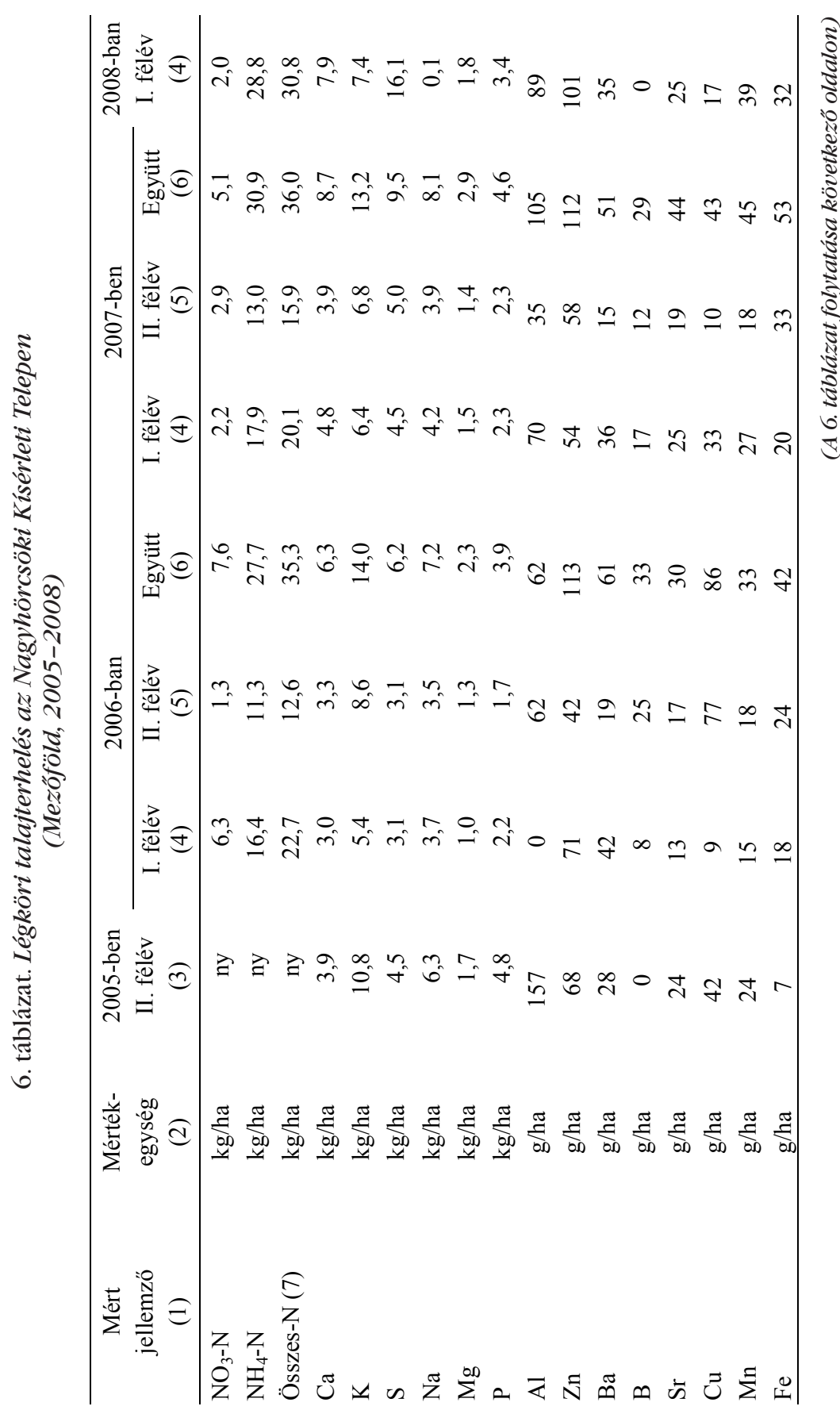




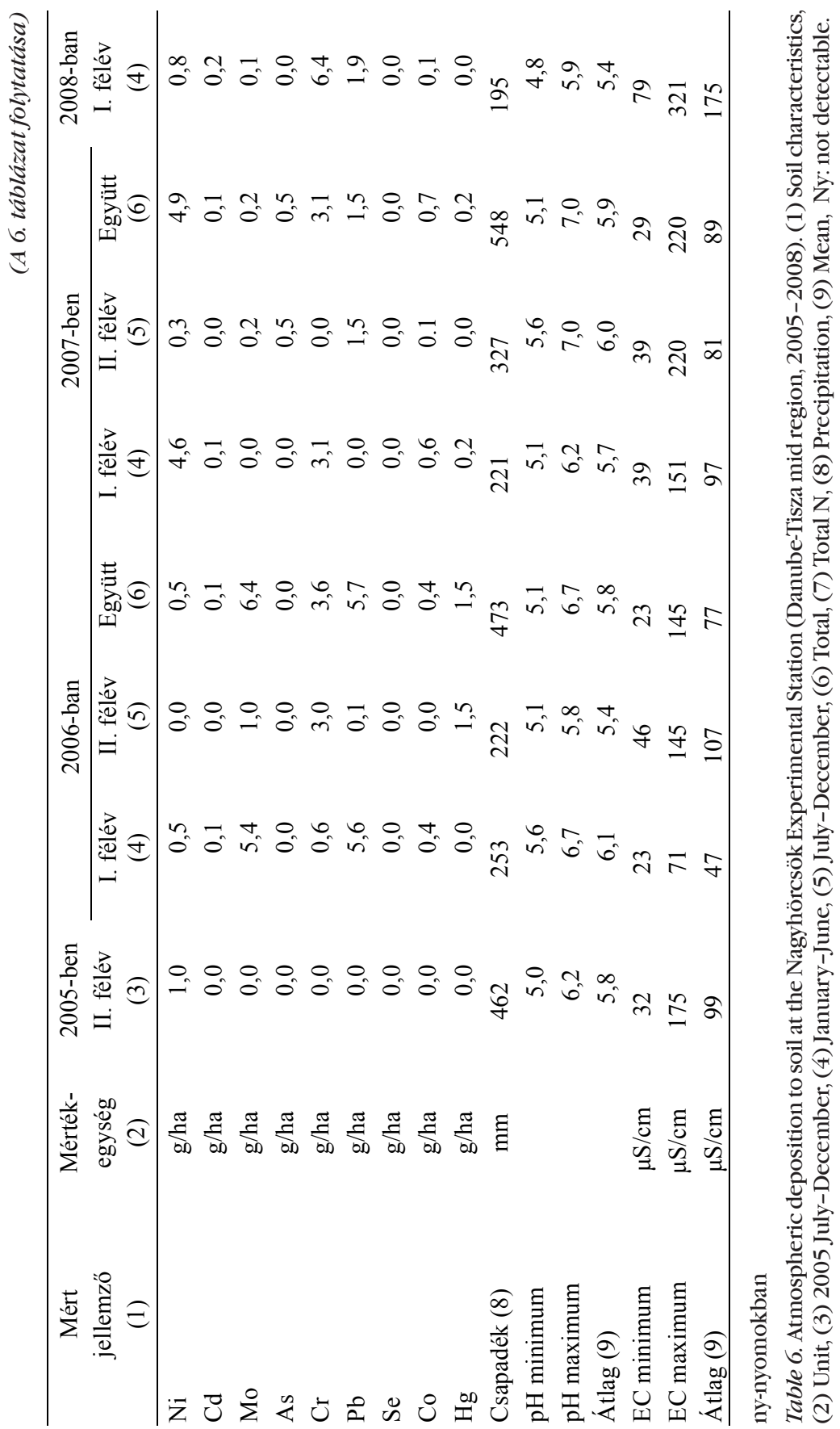


A Fe, Mn, Al talajalkotó nem szennyezó elemek, tárgyalásuktól eltekinthetünk. A légköri ülepedés lényegében fedezhette a Se, Mo, Ni elemek szembe épült mennyiségét. A Zn szükségletét mintegy 60\%-kal meghaladhatta. A B, Cu, Sr, Ba elemek terén pedig a kiülepedés többszöröse a szem elemkészletének. Jelenlegi ismereteink szerint előnyösnek minôsülhet a $\mathrm{Zn}$, Se, Mo, Cu elemekben való talajgazdagodás, amennyiben a talaj ezen elemekben nem ( $\mathrm{Zn}, \mathrm{Cu}$ ) vagy nem kellően (Se, Mo) ellátott. Nemkívánatos jelenség viszont a talaj $\mathrm{Pb}, \mathrm{Hg}$ és Cd elemekben való dúsulása, különösen hosszútávon. Takarmány és élelmiszer növények felületére, illetve a vizekbe jutva ezek a toxikus nehézfémek közvetlenül is károsíthatják az élelmiszerláncot.

A 7. táblázatban áttekintést adunk a légköri csapadékkal okozott talajterhelés mértékérôl irodalmi és saját eredményeink alapján. A bemutatott adatok arra utalnak, hogy egy vagy akár két nagyságrendbeli különbségek is adódhatnak az egyes elemek kiülepedése tekintetében a vizsgált makroelemeknél, amennyiben a háttérszennyezést és az extrém ipari területeket, tengermelléki tájakat vetjük össze. A saját kísérleti telepeinken mért elemterhelések lényegében összecsengenek a korábbi hazai mérések eredményeivel. A magyar adatok közepes szennyezésról tanúskodhatnak nemzetközi viszonylatban. A változatos hazai talajfelszín, gazdálkodási gyakorlat, ipar és közlekedés, települések, szelek hatása nyomán időben és térben nagy eltérések fordulhatnak elő. A csapadékvíz pH-ja is az erôsen savanyú 4,2 értéktôl a semleges/lúgos tartományig terjedhet.

Az általunk mért mikroelemek közül a Zn, Mn, Fe, Cu, Pb, Ni, Cd és Co összevethető Mészáros et al. (1993) korábbi eredményeivel (8. táblázat). A szomszédos Ausztriában Sager (2008) adatai is iránymutatóul szolgálhatnak. A Zn, Mn, Fe, Cu elemek kiülepedése többé-kevésbé közelálló az idézett két szerzô által közöltekkel. A B ülepedése illeszkedhet Chojnaczki (1970) által megadott $30 \mathrm{~g} / \mathrm{ha} /$ év mennyiséghez. A Ba, Sr és Mo ülepedését tekintve nincs összehasonlítási alapunk, míg a Hg esetén Anderson (1992) által megadott érték szintén tájékoztathat. Szembetûnô, hogy az Pb, Ni, Cd, Co nehézfémek kiülepedése telepeinken általában nagyságrenddel kisebb, mint a korábban Mészáros et al. (1993) által mért kiülepedés.

A Környezetvédelmi Minisztérium és a Központi Statisztikai Hivatal közlése szerint a környezetszennyező mikroelemek kibocsátásának indexe 1980 és 2000 között az alábbi mértékben csökkent: Ni 46; Hg 52; V 53; Zn 59; Cu 61; Cd 64; Se 67; Cr 70; As 74; Pb 94\%-kal. 
7. táblázat. Légköri csapadékkal okozott talajterhelés irodalmi és saját adatok alapján. Makroelemek, $\mathrm{kg} / \mathrm{ha} / e ́ v$

\begin{tabular}{lccccc}
\hline \begin{tabular}{c} 
Mért \\
jellemző \\
\multicolumn{1}{c}{$(1)$}
\end{tabular} & $\begin{array}{c}\text { Saját kísérleti } \\
\text { telepek } \\
(2)\end{array}$ & $\begin{array}{c}\text { Chojnaczki } \\
(1970)\end{array}$ & $\begin{array}{c}\text { In: Kozák } \\
\text { és } \\
\text { Mészáros } \\
(1971)\end{array}$ & $\begin{array}{c}\text { Kozák } \\
\text { és } \\
\text { Mészáros } \\
(1971)\end{array}$ & $\begin{array}{c}\text { Horváth } \\
\text { és } \\
\text { Mészáros } \\
(1984)\end{array}$ \\
\hline $\mathrm{NO}_{3}-\mathrm{N}$ & $5-20$ & $3-540^{\mathrm{xx}}$ & $0-55$ & $2-14$ & $1-9$ \\
$\mathrm{NH}_{4}-\mathrm{N}$ & $10-31$ & $4-21$ & $1-53$ & $1-19$ & $6-26$ \\
Összes-N (3) & $30-48$ & $6-540^{\mathrm{xx}}$ & $3-55$ & $5-33$ & - \\
$\mathrm{Ca}$ & $6-60$ & $1-217^{\mathrm{xx}}$ & $1-84$ & $6-67$ & $10-45$ \\
$\mathrm{~K}$ & $6-16$ & $1-12$ & $0-40$ & $2-15$ & $2-13$ \\
$\mathrm{~S}$ & $2-21$ & $2-84^{\mathrm{xx}}$ & $1-114$ & $9-39$ & $11-35$ \\
$\mathrm{Na}$ & $4-13$ & $2-5$ & $1-54$ & $2-27$ & $3-22$ \\
$\mathrm{Mg}$ & $2-16$ & $1-21^{\mathrm{xx}}$ & $0-17$ & - & $2-3$ \\
$\mathrm{P}$ & $2-6$ & $0-1$ & $0-3$ & - & - \\
$\mathrm{pH}$ & $4,2-7,0$ & $4,4-7,2$ & - & $4,3-5,8$ & $4,5-5,8$ \\
\hline
\end{tabular}

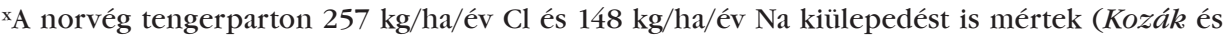
Mészáros 1971). ${ }^{\mathrm{xx}}$ Szennyezett ipari területek.

Table 7. Aerial wet deposition to soil according to literature and experimental data. Macroelements, $\mathrm{kg} / \mathrm{ha} /$ year. (1) Soil characteristics, (2) Experimental Stations data, (3) Total N. ${ }^{\mathrm{A}}$ At the Norwegian seacoast even $257 \mathrm{~kg} / \mathrm{ha} /$ year $\mathrm{Cl}$ and $148 \mathrm{~kg} / \mathrm{ha} /$ year $\mathrm{Na}$ deposition was measured. ${ }^{\mathrm{xx}}$ Polluted industrial areas.

Hasonló változások történtek egész Európában részben a környezetvédelmi intézkedések, illetve részben a korábbi „szocialista” iparágak összeomlása miatt. Mérséklődött ennek eredményeképpen a határokon átívelő légköri terhelés is. Ezeket a mérgezố nehézfémeket fốképpen a magas hômérsékletú égési folyamatok során a kohászat, fémfeldolgozás, kerámia- és vegyipar juttatja a légkörbe. $\mathrm{Az} \mathrm{Pb}$ és vegyületei károsítják az ér- és idegrendszert, Hg és vegyületei vese-, bőrr- és idegrendszert, az As, $\mathrm{Cr}$, Ni vegyületei rákkeltôk stb. Az energiatermelés, közlekedés termelte a $\mathrm{Ni}$ és $\mathrm{V}$, valamint az $\mathrm{Pb}$ és As jelentős részét (KSH 2003a, b; KvM 2002). 
8. táblázat. Légköri csapadékkal okozott talajterhelés saját és irodalmi adatok alapján Mikroelemek, g/ha/é

\begin{tabular}{lccccc}
\hline $\begin{array}{c}\text { Vizsgált } \\
\text { jellemző } \\
(1)\end{array}$ & $\begin{array}{c}\text { Saját kísérleti } \\
\text { telepek } \\
(2)\end{array}$ & $\begin{array}{c}\text { Mészáros } \\
\text { et al. } \\
(1993)\end{array}$ & $\begin{array}{c}\text { Sager } \\
(2008)\end{array}$ & $\begin{array}{c}\text { Gray } \\
\text { et al. } \\
(2003)\end{array}$ & $\begin{array}{c}\text { Anderson } \\
(1992)\end{array}$ \\
\hline $\mathrm{Zn}$ & $112-1391$ & $160-230$ & $183-1284$ & $432-1714$ & 110 \\
$\mathrm{Ba}$ & $40-79$ & - & - & - & - \\
$\mathrm{Sr}$ & $30-202$ & - & - & - & - \\
$\mathrm{Mn}$ & $33-62$ & $25-44$ & - & - & 66 \\
$\mathrm{Fe}$ & $42-119$ & $150-390$ & - & - & - \\
$\mathrm{Cu}$ & $21-153$ & $24-55$ & $8-110$ & $13-65$ & 12 \\
$\mathrm{~B}$ & $0-33$ & - & - & - & - \\
$\mathrm{Pb}$ & $2-4$ & $74-84$ & $35-186$ & $7-73$ & 35 \\
$\mathrm{Ni}$ & $0-6$ & $7-22$ & $8-43$ & $4-21$ & 3 \\
$\mathrm{Cd}$ & $0,0-0,3$ & $4,5-5,7$ & $0,6-3,0$ & $0,1-0,4$ & 1,1 \\
$\mathrm{Cr}$ & $0,3-6,4$ & - & $1,9-12,4$ & $6,9-54,9$ & 1,6 \\
$\mathrm{As}$ & $0,0-4,2$ & - & $2,8-17,9$ & - & 3,0 \\
$\mathrm{Mo}$ & $0,2-6,4$ & - & - & - & - \\
$\mathrm{Co}$ & $0,4-0,7$ & $2,3-3,1$ & - & - & - \\
$\mathrm{Hg}$ & $0,0-1,5$ & - & - & - & 0,3 \\
\hline
\end{tabular}

Megjegyzés: Chojnaczki (1970) 30 g/ha/év B ülepedéssel számol.

Table 8. Aerial wet deposition to soil according to literature and experimental data. Microelements, g/ha/year. (1) Soil characteristics, (2) Experimental Stations data. Note: Chojnaczki (1970) calculates with $30 \mathrm{~g} / \mathrm{ha}$ year B deposition.

\section{Köszönetnyilvánítás}

A kutatás a 49042 és 68665 sz. OTKA, valamint a CRO-13/2006 sz. pályázat eredményeként az NKTH és a KPI támogatásával jött létre, mely támogatás forrása a Kutatási és Technológiai Innovációs Alap.

\section{IRODALOM}

Anderson, A.: 1992. Trace elements in agricultural soils. Fluxes, balances and background values. Swedish Env. Prot. Agency. Report 4077. Uppsala. 1-40.

Bozó, L. -Horváth, Zs.: 1992. Atmospheric concentration and budget of $\mathrm{Pb}$ and $\mathrm{Cd}$ over Hungary. Ambio. 21: 324-326. 
Boxman, A. W.-Roy, C.J. H.-Peters, J.-Roelofs, G. M.: 2008. Long-term changes in atmospheric $\mathrm{N}$ and $\mathrm{S}$ throughfall deposition and effects on soil solution chemistry in scots pine forest in the Netherlands. Environmental Pollution. 156: 1252-1259.

Chojnaczki, A.: 1970. The content of mineral components in atmospheric precipitation in relation to natural and economical conditions of Poland. Polish J. of Soil Science. 3:39-46.

Chojnaczki, A.-Zórawska, B.: 1980. The content of mineral $\mathrm{N}$ in soils and yields of plants as indicator of the atmospheric pollution in Pulawy region. [In: Spáleny, J. (ed.) Proc. of the $3^{\text {rd }}$ Int. Conf. of Bioindications.] Academia. Praha. 181-187.

Deller, B.: 1988. 100 Jahre Bodenuntersuchung in VDLUFA. Bedeutung, Probleme, Erfolge. VDLUFA-Schriftenreihe. 28: 191-213.

Gray, C. W.-Mclaren, R. G.-Roberts, A. H. C.: 2003. Atmospheric accessions of heavy metals to some New Zealand pastoral soil. Sci.of Total Environment. 305: 105-115.

Horváth, L.-Mészáros, E.: 1984. The composition and acidity of precipitation in Hungary. Atmospheric Environment. 18: 1843-1847.

Kazay E.: 1904. A légköri csapadék chemiai analysise. Idójárás. 8: 301-306.

Kádár I.: 1992. A növénytáplálás alapelvei és módszerei. MTA Talajtani és Agrokémiai Kutatóintézet. Budapest.

Kádár I.: 1995. A talaj-növény-állat-ember tápláléklánc szennyeződése kémiai elemekkel Magyarországon. KTM-MTA TAKI. Budapest.

Kádár I.: 2003. Mikroelemterhelés hatása az ôszi árpára karbonátos csernozjom talajon. Agrokémia és Talajtan. 52: 105-120.

Kádár I.: 2005. A talaj és a tápláléklánc szennyeződése. [In: Antal K. et al. (szerk.) Talajvédelem Különszám.] Talajvédelmi Alapítvány. SZIE. Gödöllő. 129-137.

Kádár I.-Szemes I.-Lásztity B.: 1984. Az „évhatás” és a tápláltság összefüggése őszi rozs tartamkísérletben. Növénytermelés. 33. 2: 235-241.

Kozák M.-Mészáros E.: 1971. Magyarországi csapadékvizek kémiai összetétele és mezőgazdasági jelentôsége. Agrokémia és Talajtan. 20: 329-352.

KSH: 2003a. Magyarország környezetterhelési mutatói: Központi Statisztikai Hivatal, Környezetvédelmi Minisztérium. Budapest.

KSH: 2003b. Magyarország környezeti állapota nemzetközi összehasonlításban. Központi Statisztikai Hivatal. Budapest.

Kucharski, R.-Marchwinska, E.-Gzyl, J.: 1994. Agricultural policy in polluted areas. Ecological Engineering. 3: 299-312.

KvM: 2002. Adatok hazánk környezeti állapotáról. Környezetvédelmi Minisztérium Környezetgazdálkodási Igazgatósága. Budapest.

Lásztity B.-Szemes I.-Radics L.: 1993. Mútrágyahatások vizsgálata rozs monokultúrában. Agrokémia és Talajtan. 42: 309-324.

Liebig, J. von (1840-1876) (szerk. Kádár I.): 1996. Kémia alkalmazása a mezőgazdaságban és az élettanban. MTA TAKI Budapest.

Mansfield, T. A.-Freer-Smith, P. H.: 1981. Effects of urban air pollution on plant growth. Biol. Rev. 56: 343-368. 
Mészáros E.-Molnár Á.-Horváth Zs.: 1993. A mikroelemek légköri ülepedése Magyarországon. Agrokémia és Talajtan. 42: 221-228.

Mészáros E.: 2005. Hogyan fedezték föl a levegőt? Adalékok a légkör kutatásának történetéhez. Magyar Tudomány. 426-437.

Molnár, Á-Mészáros, E.-Bozó, L.: 1993. Elemental composition of atmospheric aerosol particles under different conditions in Hungary. Atmospheric Environment. 27A. 15: 2457-2461.

MSZ ISO 5667-10: Magyar Szabvány. Vízminőség. Mintavétel. Magyar Szabványügyi Hivatal. Budapest. 1995.

Munger, J. W.: 1982. Chemistry of atmospheric precipitation in the N-C US: Influence of $\mathrm{SO}_{4}, \mathrm{NO}_{3}, \mathrm{NH}_{3}$ and calcareous soil particulates. Atmospheric Environment. 16: $1633-1645$.

Nriagu,J. O.-Pacyna, J. M.: 1988. Quantitative assessment of worldwide contamination of air, water and soils by trace metals. Nature. 333: 134-139

Nriagu, J. O.: 1989. A global assessment of natural sources of atmospheric trace metals. Nature. 338. 47-49.

Odén, S.: 1979. The sulphur budget of Sweden during this century. Nordic Hydrology. 155-170.

Ross, H. B.: 1987. Trace metals in precipitation in Sweden. Water, Air and Soil Pollution. 36: 349-363.

Sager, M.: 2008. Macro- and microelements of mineral fertilizers sold in Austria. Kézirat. MTA Talajtani és Agrokémiai Kutatóintézet. Budapest. 11.

Saussure, de Th.: 1804. A növények kémiai kutatása. Kecskeméti Főiskola Nyomda Kecskemét. 2004.

Shewchuk, S. R.: 1982. An acid depositin perspective for N-E Alberta and N-Saskatchewan. Water, Air and Soil Pollution. 18: 413-419.

Sillanpää, M.: 1990. Micronutrient assessment at the country level: an international study. FAO Soils Bulletin N. 63. Rome.

Warda, Z.-Chojnazcki, A.-Pasternaczki, J.: 1980. The content of $\mathrm{Zn}, \mathrm{Pb}$ and $\mathrm{S}$ in soil and plants in lysimeter experiments as indicators of atmospheric pollution in zinc metallurgy region. [In: Spáleny, J. (ed.) Proc. of the $3^{\text {rd }}$ Int. Conf. of Bioindications.] Academia. Praha. 403-410.

A szerzôk levelezési címe - Address of the authors:

Dr. Kádár Imre-Koncz József-Ragályi Péter

MTA Talajtani és Agrokémiai Kutatóintézet

Budapest

Herman O. u. 15.

H-1022 